\title{
DIE ROOMSKATOLIEKE LEER, SIN EN BETEKENIS VAN ARTIKEL 3(B) VAN DIE APOSTOLICUM
}

Deur: DR. P. J. KOEKEMOER.

\section{A. DIE GROEI VAN DIE ROOMS-KATOLIEKE MARIOLOGIESE DOGMA.}

Die valgende dogmenhistoriese gegewens toon duidelik 'n uitbreiding van die ,conceptus est de Spiritu Sancto, natus ex Maria Virgine" aan. Die uitbreiding vind nie plaas aan die kant van die „conceptus est de Spiritu Sancto" nie, maar aan die kant van die „natus ex Maria Virgine". Dwarsdeur die dogmenhistoriese lyn vind ons 'n sekere terughoudendheid van die spreke aangaande die Heilige Gees i.v.m. die „verwekking” van Jesus Christus. Die „ek Marias tes parthenou” (,ex Maria Virgine”) van die Nuwe Testament, tegelykertyd ook die belydenis van die vaders op die Eukumeniese konsilies, is deur die konsilies van Rome en die uitsprake van die pous ,ex cathedra” uitgebrei. Agtereenvolgens sien ons dat Maria gekwalifiseer word as „Mater Christi ideoque vere et proprie Dei genetrix", vgl. die uitspraak van Johannes II (533-535 n.C.): Mater Domini Dei nostri Christi Maria semper virgo debeat apellari .. ; (die Conc. Constantinopolitum) (553 n.C.) „et incarnatus de sancta gloriosa Dei genitrice et semper Virgine Maria”; „Dei genitricem sanctam semperque Virginem et immaculatam Mariam", (van die Lutheraanse Konsilie, 649). Maria is die „Virgo ante partum, in partu et post partum". Sy is nie alleen sonder erfsonde ,immaculata concepta") nie, maar die Conl. Trid. maak haar vry van alle sonde: posse in tota vita peccata omnia etiam venialia vitare, nisi ex speciali Dei privilegio, quemadmodum de Beata Virgine tenet Ecclesia.

Reeds by Bernhard van CLAIRVEAUX het sy in grote verering gestaan: „Stadeamus et nos ad ipsum per eam escendere, qui per ipsam ad nos descendit, per eam venire in gratiam ipsuis, qui per eam in nostram miseriam venit per te eccensum habeamus ad filium; o benedicte inventrix gratiae, genetrix vitae, mater salutis; ... domina nostra, mediatrix nostra, advocata nostra .."1)

So vroeg as gedurende die eerste drie eeue is die aandag op Maria gevestig deur Marialegendes en apokriewevertellinge Reeds ORIGENES het daarop gewys dat die bedoeling van die

1) A von Harnack: Lehrbuch er Dogmengeschichte III bls. 658 siteer uit 'n preek van Bernard, Sermon. 2 in adv. dom. 
apokriewe prot-Evangelie van Jakobus is om die maagdelike waarde van Maria deurgaans te handhaaf. „Die prot-Evangelie van Jakobus het dus een groot doel: Die vereniging van Maria. Dit gaan meer om die beklemtoning van die maagdelikheid as om die suiwerheid en heiligheid van haar eersgebore Seun. Die Persoon van Jesus tree op die agtergrond. Jesus is slegs een van die byfigure. Alles draai om Maria ${ }^{2}$ ). So groei reeds heel vroeg, so verklaar HENNECKE, die beeld van die moeder van God, wat later ,veel meer as die hemelse Vader", diegene wat hulp en genade soek, na haar getrek het. ${ }^{3}$ )

Reeds by IRENAEUS vind HARNACK een van die wortels van die Mariavering. ${ }^{4}$ ) Ook PIERIUS, ALEXANDER van Alexandrieë, EUSEBIUS en ATHANASIUS het haar "theotokos" genoem. Sy is genoem "virgo ante partum" en ,in partu" deur Clemens ALEXANDRINUS en „virgo post partum" deur ORIGENES ${ }^{5}$ ).

Alhoewel die wortels van die Mariaverering reeds so vroeg as by IRENAEUS aangeneem kan word, is dit eers sedert die vierde eeu dat die Mariaverering in die Kerk duideliker word ${ }^{6}$ ). Veral AMBROSIUS en HIERONYMUS het in hulle stryd teen JOVINIANUS die Mariaverering in die Kerk bevorder. AMBROSIUS is by uitnemendheid die vertolker van die aktiewe deelname van die heilige maagd in die verlossingsplan; Mariaverhale word in sy tyd in die Kerk gewettig.')

Die Maria-verering hang ook saam met die asketiese ideaal wàt in die 4de eeu in die Kerk gebloei het, soos blyk uit die volgende uitspraak van pous Siricius: ${ }^{8}$ ) Pous SIRICIUS, 384-398 n.C. leer: „Sane non possumus negarde de Mariae filiis jure reprehensum, meritoque vestram sanctitatem abhorruisse, quod ex eodem utero virginali, ex quo secundum carnem Christus natus est, alius partus effusus sit. Neque enim elegisset Dominus Jesus nasci per virginem, si eam judicasset tam incontinentem fore, ut illud genitale Dominici corporis, illam aulam regis aeterni concubitus humani semine coinquinaret. Qui enim hoc adstruit, nihil aliud nisi per fidiam Judaicam adstruit, qui dicunt eum non potuisse nasci ex virgine. Namsi hanc accipiant a sacerdotibus auctoritatem, ut videatur Maria partus fudisse plurimos, maiore

2) Dr. H. Mulder: „De Eerste Hoofdstukken van het Evangelie naar Lukas in hun structurele samehang".

Dissertasie, Amsterdam, 1948, bls. 192-193.

3) E. Hennecke, Neutetamentliche Apocryphen. Tübingen-Leipzig 1904, gesiteer deur Dr. H. Mulder, A.W. bls. 193, vgl. ook Loofs, A.W. bls 315.

4) Harnack: .Lehrbuch der Dogmengesch". I, bls. 597: "Anderseits ist unverkennbar, dass die spätere Mariënverehrung an der Paralelle Eva-Maria eine ihrer Wurzeln hat."

5) Harnack: „Lehrbuch der Dogmengesch”. II. bls. 476. Loofs, A.W. bls. 315.

c) Harnack: ",Lehrbuch der Dogmengesch". II, bls. 477.

7) Harnack: "Lehrbuch der Dogmengeschichte." II, bls. 477.

8) Prof. Dr. J. A. A. A. Stoop word bedank vir sy hulp in verband met al die latynse vertalings in hierdie artikel. 
studio veritatem fidei expugnare contendunt." $H$. DENZINGER, A.W. 91. VERT'ALING: „Seer seker kan ons nie ontken dat (die verhaal) omtrent seuns van Maria tereg afgekeur is en tereg $u$ hẹiligheid aanstoot gegee het, (naamlik) dat uit dieselfde maagdelike skoot, waaruit Christus volgens die vlees gebore is, 'n ander geboorte sou plaasgevind het. Die Here Jesus sou immers ook nie gekies het om deur bemiddeling van 'n maagd gebore te word nie, indien Hy (sou) geoordeel het dat sy so onbeheersd sou wees om daardie moederskoot wat aan die Here se liggaam geboorte geskenk het, daardie paleis van die ewige Koning, te besoedel met die saad van die omgang met 'n man. Wie dit immers beweer, beweer niks ander as die valsheid van die Jode nie, wat sê dat Hy nie uit die maagd gebore kon word nie. Want indien hulle hierdie uitspraak op gesag van die priesters aanvaar, dat dit lyk of Maria aan baie kinders die lewe geskenk het, dan streef hulle met al te groot ywer daarna om die waarheid van die geloof te skend".

Saam met die opkoms van die asketiese en virginiteitsideaal in die 4de eeu, 'n ideaal wat deur die hoogstaande kuisheid en maagdelikheid van Maria geinspireer en bevorder is, hang ook saam die verering van heiliges, d.w.s. martelare, askete en heroë?). Dit is egter eers sedert die vyfde eeu dat Maria as ,heilige" op die voorgrond tree. „Auch Maria ist noch im vierten Jahrhundert hinter den Heiligen zurückgetreten ... Marienkirchen kannte das vierte Jahrhundert noch nicht. ${ }^{11}$ ) Eers sedert die begin van die vyfde eeu hoor ons van Maria-kerke, terwyl kerke van ander heiliges lank reeds bekend was ${ }^{11}$ ).

Die wordende Maria-,,dogma" is volgens HARNACK ook deur AUGUSTINUS eerder versterk as verswak: AUGUSTINUS het met. AMBROSIUS en HIERONYMUS saamgestem teen JOVINIANUS ,deur 'n vrou het die dood gekom en deur 'n vrou die lewe”. Aangaande Maria sê hy: ,ipsa conditio nascendi solvitur gratia renascendi". (Op. imp. 4, 22). ${ }^{11}$ a). Wanneer AUGUSTINUS sy beskouing oor die maagdelike geboorte uiteenset (Enchiridion ad Laurentium, par. 34) is dit duidelik dat Maria, volgens hom, in partu maagd bly. Die versterking van die Mariologie deur AUGUSTINUS sien HARNACK so: „Eben weil Augustin die Sündhaftigkeit aller Menschen, auch der Heiligen, zuerst energisch betont hat, die Maria aber ausnahm, het er dazu beigetragen, der Maria eine besondere Stellung zwischen Christus und den Christen zu gebeden,.. ${ }^{12}$ )

9) F. Loofs: „Leitfaden zum Studium der Dogmengeschichte”. 4de Uitgawe. Halle 1906 . Bls. 314.

10) F. Loofs: A.W. bls. 314-315.

11) A. von Harnack: "Lehrbuch der Dogmengeschichte" II. bls. 476 .

11a) A. von Harnack: "Lehrbuch der Dogmengeschigte" III, bls. 232.

12) A. von Harnack: "Lehrbuch der Dogmengeschigte" III, bls. 232. 
POUS JOHANNES II, (533-535 n.C.) leer soos volg:-

Justinianus (siquidem) imperator filius noster, ut ex eius epistolae tenora cognovistis, de his tribus quaestionibus ora certamina fuisse signivicavit, utrum unus ex Trinitate Christus et Deus noster dici possit: hoc est una de tribus personis Sanctae Trinitatis sancta persona. An Deus Christus carne pertulerit impassibilis deitate. An proprie et veraciter (Dei genitrix marterque Dei Verbi ex ea incarnati) mater Domini Dei nostri Christi Maria semper virgo debeat appellari . . G Gloriosam vero Sanctam semper virginem Mariam et proprie et veraciter Dei genitricem matremque Dei Verbi ex ea incarnati ab hominibus catholicis confiteri recte docemus. Proprie namque et veraciter idem ipse ultimis temporibus incarnatus, ex Sancta et gloriosa Virgine matre nasci dignatus est. Propterea ergo, quia proprie et veraciter Dei Filius ex ea incarnatus et natus est, ideo proprie et veraciter matrem Dei ex ea incarnati et nati esse confitemur et (proprie quidem) ne Dominus Jesus per honorificentiam vel gratiam nomen Dei accepisse credatur, sicut Nestorius sentit insulsus: veraciter autem ideo, ne in phantasmate aut aliquo modo non veram sumpsisse carnem credatur ex virgine, sicut asseruit impius Euthyches”. DENZINGER, A.W. 201 en 202. VERTALING: „Keiser Justinianus, ons seun, soos julle uit die inhoud van sy brief weet, het aangedui dat oor hierdie drie vrae twiste opgerys het: Of Christus en ons God een van die Drieëenheid genoem kan word, d.w.s. een heilige Persoon van die drie Persone van die Heilige Drieëenheid; of die God, Christus, in die vlees tot die einde toe gely het alhoewel $\mathrm{Hy}$ in sy Godheid nie kon ly nie, en of die moeder van die Here ons God, Christus, Maria, (moeder van God en moeder van God die Woord uit haar vlees geword het), tereg en in waarheid altyd maagdelik genoem moet word . .

Ons leer dat Maria tereg deur die katolieke bely word as Roemvol, waarlik Heilig, altyd maagdelik en werklik en waarlik moeder van God die Woord, wat uit haar vlees geword het. Want toe Hyself in die laaste tye vlees geword het, het Hy dit werk. lik en waarlik waardig geag om uit die heilige en roemvolle moeder-Maagd gebore te word. Derhalwe dus, omdat die Seun van God werklik en waarlik uit haar vlees geword het en gebore is, daarom bely ons dat sy werklik en waarlik die moeder is van God, wat uit haar vlees geword het en gebore is, en (werklik voorwaar), sodat dit nie geglo word dat die Here Jesus deur eerbetoon of genade die naam van God ontvang het nie, soos die dwase Nestorius dink: waarlik egter daarom (bely ons dit), sodat dit nie geglo word dat $\mathrm{Hy}$ in spookgedaante of op een of ander manier, nie reële vlees uit die Maagd aangeneem het nie, soos die goddelose Eutyches bevestig het". 

NICUM, V. leer:

Can. 2 Si quis non confitetur Dei Verbi duas esse nativitates, unam quidem ante saecula ex patre sine tempore incorporaliter, alteram vero in ultimis diebus eiusdem ipsius, qui de coelis descendit, et incarnatus de sancta gloriosa Dei Genetrice et Semper Virgine Maria, natus est ex ipsa, talis Anathema sit. DENZINGER, A.W. 214. VERTALING: „As iemand nie bely dat daar twee geboortes is van God die Woord nie, - die een voorwaar tydloos en onliggaamlik, voor die (begin van die) eeue, uit die Vader: die tweede egter in die laaste dae van Homself, wat uit die hemele neergedaal het, vlees geword het uit die heilige roemvolle Moeder van God en altyd maagdelike Maria, en uit haar gebore is, laat so 'n persoon dan verdoem wees".

Toe Pasgasius RADBERTUS en RATMANUS in diskussie getree het oor die Avondmaal, (9de eeu), het die ,de partu virgines” sydelings ter sprake gekom. Vir RATRAMUS is dit 'n ingewing van die duiwel dat in Germanië mense is wat loën dat Christus op natuurlike wyse uit die maagd Maria gebore is. Hy maak egter hierdie skolastiese onderskeid dat by sy erkenning van die perpetuele maagdskap en die "partus clauso utero", hy die klemtoon daarop lê dat die geboorte natuurlik plaasgevind het deur die wonder clauso utero. RADBERTUS leer teenoor RATRAMUS dat die geboorte bowe-natuurlik plaasgevind het en dat met die geboorte Jesus Christus die moederliggaam verlaat het op ' $n$ ander wyse as die gewone..$^{13}$ ) RADBERTUS troos die verontruste nonne daarmee dat die Kerk altyd aan die "clauso utero" sal vashou, want as Christus op natuurlike wyse gebore is, dan was Hy niks meer as 'n gewone mens, onder die natuurwette, onder die sondige natuur, nie vry van erfsmet nie. ${ }^{14}$ )

Enkel jare na die dood van ANSELMUS, wat die onbevlekte ontvangenis van Maria geloën het, ${ }^{15}$ ) vind ons in Lyon 'n fees (1140 n.C.) ter ere van die onbevlekte ontvangenis. In die Ooste en Weste het voor hierdie tyd mariafeeste bestaan, maar volgens HARNACK was dit geen feeste van die onbevlekte ontvangenis nie. ${ }^{16}$ ) BERNHARD het hierdie lg. feeste nie goedgekeur nie. ${ }^{17}$ ) Nieteenstaande sy hoë agting vir die persoon van Maria, waarna ons reeds verwys het, hou BERNHARD die onbevlekte ontvange-

13) A. von Harnack: Lehrbuch der Dogmengeschichte III, voetnoot bls. 308. Vgl. ook bls. 317: Ratramnus leer: „das Natürliche ist durch ein Wunder geschehen”, Radbertus daarteenoor: „Es ist etwas Wider natürliches geschehen".

14) Vgl. A. von Harnack: Lehrbuch, voetnoot bis. 308 .

15) Cur Deus Homo I, 1, 16.

16) A. von Harnack Lehrbuch III, bls. 655.

17) A. von Harnack ,Lehrbuch . . ." III, bls. 655 verwys na Bernhard: ep. 174, ad canonicos Lugd. 
nis as 'n pregrogatief vir Christus alleen. Die idee van 'n onbevlekte ontvangenis het dus nie sonder teenstand van verskillende teoloë gekom nie. BONAVENTURA en die skolastici voor SCOTUS loën die onbevlekte ontvangenis. ${ }^{18}$ ) THOMAS glo slegs aan 'n heiliging ,in utero" en 'n besondere werking van genade op Maria, na die konsepsie. ${ }^{19}$ ) SCOTUS hou dit vir „probabile” dat Maria sonder sonde (onbevlek) ontvang is en dat sy vry is van die concupisentia carnis. ${ }^{\circ}$ ) Sedertdien het die Franciskaners met krag teen die Dominikaners (Tomiste) vir die lg. opvatting, nl. dat Maria vry is van die ,concupiscentia carnis", ingetree ${ }^{12}$ ).

Die onbevlekte ontvangenis het in die middeleeue 'n strydvraag gebly:-

MARTINUS I, 649-653 (655) n.C. leer:-

Conc. Lateranense, 649 n.C. Contra monotheletas:

Si quis secundum sanctos Patres non confitetur proprie et secundum veritatem ipsum unum sanctae et consubstantialis et venerandae Trinitatis Deum Verbum e coelo descendisse, et incarnatum ex Spiritu Sancto et Maria semper Virgine, et hominem factum . . condemnatus sit. H. DENZINGER, A.W. 255.

VERTALING: „As iemand nie, in navolging van die heilige Vaders, bely dat God die Woord werklik en waaragtiglik self een van die heilige konsubstansiële en aanbiddelike Drie-eenheid, uit die hemel neergedaal het en vlees geword het uit die Heilige Gees en die altyd maagdelike Maria, en mens geword het nie ... laat hy dan veroordeel wees."

ADEODATUS, 672-676 n.C. Conc. Toletanum XI, 675 n.C. (De Incarnatione). De his tribus personis solam Filii personam pro liberatione humani generis hominem verum sine peccato de sancta et immaculata Maria Virgine credimus assumpsisse, de qua novo ordine novaque nativitate est genitus; novo ordine, quia invisibilis divinitate, visibilis monstratur in carne; nova autem nativitate est genitus, quia intacta virginitas et virilem coitum nescivit et foecundatam per Spiritum Sanctum carnis materiam ministravit. Qui partus Virgines nec ratione colligitur, nec exemplo monstratur; quod si ratione colligitur, non est mirabile; si exemplo monstratur, non erit singalare. Nec tamen Spiritus Sanctus Pater esse credendus est Filii, pro eo quod Maria eodem Sancto Spiritu obumbrante concepit: ne duos patres Filii videamur esserere, quod utique nefas est dici. H. DENZINGER, A.W. 282.

VERTALING: „Ons glo dat, van hierdie drie Persone, uitsluitend die Persoon van die Seun, om die mensheid se bevryding ontwil sonder sonde 'n ware mens aangeneem het (aan Hom toege-

18) A. Harnack: Lehrbuch III, bls. 656.

10) A. Harnack: Lehrbuch III, bls. 656 .

20) In Sent. III Dist 3 Q 1 aangehaal deur Harnack Lehrbuch III, bls. 656 .

21) A. Harnack: „Lehrbuch" III. bls. 656 . 
voeg het) uit die heilige en onbevlekte Maagd Maria, uit wie Hy gespruit het op 'n vreemde wyse en 'n nuwe geboorte; deur 'n nuwe wyse, omdat $\mathrm{Hy}$, onsigbaar in Sy Godheid, Homself sigbaar toon in sy vlees; uit 'n nuwe geboorte gespruit omdat die ongeskonde maagdelikheid sowel die byslaap van 'n man nie geken het nie en ook die stof van die vlees verwek deur die Heilige Gees, verskaf het. En hierdie geboorte uit 'n Maagd word nie deur die rede verstaan nie, en ook nie deur 'n voorbeeld aangewys( geîllustreer) nie; omdat dit nie wonderlik is indien dit deur die rede verstaan word nie, en nie enig in sy soort sal wees indien dit deur 'n (vroeëre) voorbeeld aangewys (geïllus . treer word nie. Nogtans moet dit nie geglo word dat die Heilige Gees, omdat Maria ontvang het nadat Sy deur die Heilige Gees oorskadu is, die Vader van die Seun is nie, sodat dit lyk asof ons beweer dat daar twee Vaders van die Seun was nie, wat in geen geval mag gesê word nie."

EUGENIUS IV, 1431-1447 Conc. Florentinum, 1438-1445 Oecumenicum XVII, leer:-

Firmiter credit, profitetur et praedicat . . . Dei Filium ex Patre genitum ... propter salutem humani generis veram hominis integramque naturam ex immaculato utero Mariae Virginis assumpsisse et sibi in unitatem personae copulasse tanta unitate, ut quidquid ibi Dei est non sit ab homine separatum . . . H. DENZINGER. A.W. 708.

VERTALING: „(Die Kerk) glo vas, bely en spreek dat . . die Seun van God wat uit die Vader gebore is . . . om redding van die mensheid ontwil die ware en volledige natuur van ' $n$ mens uit die onbevlekte skoot van die Maagd Maria aangeneem het en met Homself tot ' $n$ eenheid van persoon verenig het, in so 'n eenheid, dat wat daar ook al goddelik is, nie van die mens geskei is nie..."

PAULUS IV, 1555-1559. De Trinitate et Incarnatione contra Unitarios, leer:-

"... aut Dominum nostrum non esse Deum verum eiusdem substantiae per omnia cum Patre et Spiritu Sancto: aut eundum secundum carnem non esse conceptum in utero beatissimae semperque Virginis Mariae de Spiritu Sancto, sed sicut ceteros homines ex semine Joseph; . . . aut eandem beatissiman Virginem Mariam non eses veram Dei meatrem, nec perstitisse semper in virginitatis integritate, ante partum scilicet, in partu et perteouo post partum, ex parte omnipotentis Dei Patris et Filii et Spiritus Sancti apostolica auctoritate requiremus et monemus etc ... DENZINGER, A.W. 993.

VERTALING: , . . . of dat ons Heer nie ware God is, in alle opsigte van dieselfde wese soos die Vader en die Heilige Gees nie, of dat Hy volgens die vlees nie ontvang is van die Heilige 
Gees in die skoot van die allersaligste en altyd maagdelike Maria nie, maar soos die ander mense uit die saad van Josef . . of dat dieselfde allerlaagste Maagd Maria nie ware moeder van God is nie, en dat sy nie altyd in die ongeskondenheid van maagdelikheid gebly het, naamlik voor die geboorte, tydens die geboorte en altyddurend na die geboorte nie, eis en waarsku ons in naam van die almagtige God die Vader en die Seun en die Heilige Gees met apostoliese gesag (dat) ... ens."

SIXTUS IV, 1471-1484. De immaculata conceptione B.M.V. 1476. (DENZINGER, A.W. 734 en 735).

Cum praeexcelsa meritorum insignia, quibus regina coelorum, Virgo Dei genitrix gloriosa, sedicus praelata aethereis, sideribus quasi stella matutina praerutilat, devotae considerationis indagine perscrutamur ... dignum, quin potius debitum reputamus, universos Christi fideles, ut omnipotenti Deo (cusius providentia eiusdem Virgines humilitatem ab aeterno respiciens, pro reconcilianda suro auctori humana natura lapsu primi hominis aeternae morti abnoxia, eam sui Unigeniti habitaculum Sancti Spiritus praeparatione constituit, ex qua carnem nostrae mortalitis pro redemtione populi sui assumeret, et immaculata Virgo nihilominus post partum remaneret) de ipsius immaculatae Virgines mira conceptione gratias et laudes referant ... indulgentiis et peccatorum remissionibus invitare, ut exinde fiant eiusdem Virgines meritis et intercessione divinae gratiae aptiores.

Sane cum S. Romana Ecclesia de intemeratae semperque Virgines Mariae conceptione publice festum soleminter celebret, et speciale ac proprium super hoc officium ordinaverit . . eadem gloriosam et immaculatam Dei genitricem absque originalis peccati macula fuisse conceptam, moraliter peccare, vel esse haereticos, iusdem immaculatae conceptionis officium celebrantes, audientes sermones illorum, qui eam sine huiusmodi macula conseptam esse affirmant, peccare graviter . . H. DENZINGER, A.W. 734 en 735.

VERTALING: „Wanneer ons met ondersoek van eerbiedige beskouing die alleruitmuntendste eerbewyse vir haar verdienstes ondersoek, waarmee die koningin van die hemele, die roemvolle Maagd, moeder van God, wat verhef is bo die (woon)-plekke van die ether, soos 'n môrester helderder skitter as die hemelliggame ... God het in Sy voorsienigheid die nederigheid van die Maagd beskou en haar, met die oog op die versoening van die menslike natuur (wat deur die val van die eerste mens die ewige dood skuldig was) met sy Skepper, uitverkies, met die voorbereiding van die Heilige Gees, as 'n woning van Sy Eniggeborene, waaruit Hy die vlees van ons sterflikheid ter wille van Sy volk se loskoping (verlossing) sou aanvaar, en dit terwyl sy 
nietemin na die geboorte 'n onbevlekte Maagd sou bly. Daarom ag ons dit gepas, ja beter nog: 'n plig, om die gesamentlike getroues (gelowiges) van Christus uit te nooi dat hulle aan die Almagtige God dank en lof moet toebring vir die wonderlike ontvangenis van dieselfde onbevlekte Maagd. Ons sal hulle daartoe uitnooi deur middel van aflate en vergewing van sondes, sodat hulle as gevolg daarvan (d.i. van hulle deelname) deur die verdienstes en die tussenkoms van dieselfde Maagd die goddelike genade beter kan verdien.

Seer seker, wanneer die H. Roomse Kerk openlik 'n fees van die onbevlekte en altyd maagdelike Maria plegtig vier, en op besondere en aparte wyse oor hierdie diens bepaal ... dat hulle sedelik sondig, of ketters is, (as hulle sê) dat dieselfde glorievolle en onbevlekte moeder van God sonder smet van erfsonde ontvang was; dat hulle swaar sondig, as hulle die diens van dieselfde onbevlekte ontvangenis opdra, as hulle die leringe beluister van hulle wat bevestig dat sy sonder smet van hierdic soort ontvang is. .."

Die CONC. TRID. 1545-1563 Dacretum super peccato orginali.

... Declarat tamen haec ipsa sancta Synodus, non esse suae intentionis, comprehendere in hoc decreto, ubi de peccato originali agitur, beatam et immaculatam Virginem Mariam Dei genitricem, sed observandas esse constitutiones felicis rezordationis SIXTI Papae IV, sub poenis in eies constitutionibus contentis, quas innovat ... DENZINGER, A.W. 792.

VERTALING: „Hierdie heilige Sinode self verklaar nogtans, dat dit nie in sy bedoeling is om in hierdie dekreet, waaroor die erfsonde gehandel word, die salige en onbevlekte Maagd Maria, moeder van God, in te sluit nie, maar dat die bepalinge van Pous Sixtus IV van salige nagedagtenis in ag geneem moet word, onder die strawwe wat in daardie bepalinge bevat is, en wat hy (die Sinode) hernu."

Die volgende belangrike afkondiging i.v.m. die sondeloosheid van Maria kom van Pous Alexander VII.

ALEXANDER VII, 1655-1667. De Sensu verborum. Conelii Jansen.

... Vetus est Christi fidelium erga eius beatissimam matrem Virginem Mariam pietas sentientium, eius animam in primo instanti creationis atque infusionis in corpus fuisse speciali Dei gratia et privilegio, intuitu meritorum Jesu Christi eius filii, humani generis Redemptoris, a macula peccati originalis praeservatam immunem, atque in hoc sensu eius conceptionis festivitatem solemni ritu colentium et celebrantium ... 
Constutiones et decreta a Romanis Pontificibus . . . edita in favorem sententiae assenrentis, animam beatae Mariae Virginis in sui creatione et in corpus infusione Spiritus Sancti gratia donatam et a peccato originali praeservatam fuisse . . . innovamus. DENZINGER, A.W. 1100.

VERTALING: „Vanuit die ou dae bestaan daar 'n verering vanweë die gelowiges van Christus vir Sy allersaligste mozder, die Maagd Maria: hulle voel dat haar siel op die eerste oomblik van sy skepping en sy instorting in die liggaam, deur 'n besondere genade en voorreg van God, met die oog op die verdienstes van Jesus Christus haar seun, die Verlosser van die mensheid, ongeskonde gehou is, (bewaar is) van die erfsonde se smet; en in hierdie oortuiging vereer en vier hulle die fees van haar ontvangenis met 'n plegtige seremonie.

Ons hernu die bepalinge en dekrete wat deur die Roomse Biskoppe ... uitgevaardig is ten gunste van die mening wat bevestig dat die siel van die salige Maagd Maria, by haar eie skepping en by die uitstorting van die Heilige Gees in haar liggaam, genade ontvang het en van die erfsonde bewaar is ..."

PIUS IX, 1846-1878. Definito immaculatae conceptionis B.M.V. 8 Des. 1854.

... Ad honorem Sanctae et Individuae Trinitatis, ad decus et ornamentum Virginis Deiparae, ad exalatationem fidei catholicae et christianae religionis augmentum, auctoritate Domini nostri Jesu Christi, beatorum Apostolorum PETRI et Pauli ac Nostra declaramus, pronontioamus et definimus, doctrinam, quae tenet, beatissimam Virginem Mariam in primo instanti suae conceptionis fuisse singulari omnipotentis Dei gratia et privilegio, intuitu meritorum Christi Jesu Salvatoris humani generis, ab omni originalis culpae labe praeservatam immunem, esse a Deo revelatum atque idcirco ab omnibus fidelibus firmiter constanterque credendam . . ." DENZINGER, A.W. 1641.

VERTALING: „Tot eer van die Heilige en Ondeelbare Drieëenheid, tot verheerliking en sieraad van die Maagd, moeder van God, tot verheffing van die katolieke geloof en tot uitbreiding van die Christelike godsdiens; op gesag van ons Heer Jesus Christus, van die salige apostels Petrus en Paulus en op ons eie gesag, verklaar ons, spreek ons uit en bepaal ons soos volg: Die leer, wat inhou dat die allersaligste Maagd Maria op die eerste oomblik van haar ontvangenis deur 'n alleenstaande genade en voorreg van die Almagtige God, met die oog op die verdienstes van Christus Jesus, die Redder van die mensheid, ongeskonde gehou is van enige val in die erfsonde, is deur God geopenbaar en moet daarom deur alle gelowiges vas en standvastiglik geglo word ...." 
(OPMERKING: Die term ,met die oog op die verdienstes van Christus Jesus, die Redder van die mensheid" dui daarop dat die Mariologie gaan steun soek by die Christologie!)

\section{DIE LIGGAMLIKE HEMELVAART VAN MARIA.}

Pous XII kondig op 1 Nov. 1950 die jongste mariologiese dogma af, nl. haar liggaamlike hemelvaart:-

Definitio assumptionis B.M.V. Ex Constitutione Apoztolica „Munificentissimus Deus". Haec omnia Sanctorum Patrum ac theologorum argumenta considerationesque Sacris Litteris, tanquam ultimo fundamento, nituntur; quae quidem almam Dei Matrem nobis veluti ante oculos proponunt divino Filio suo coniunctissimam, eiusque semper participartem sortem. Quamobrem quasi impossibile videtur eam cernere, quae Christum concepit, peperit, suo lacte aluit, eumque inter ulnas habuit pectorique obstrinxit suo, ab eodem post terrestrem hanc vitam, etsi non anima, corpore tamen separatum. Cum Redemptor noster Mariae Filius sit, haud poterat profecto, utpote divinae legis observator porfectissimus, praeter Aeternum Patrem, Matrem quoque suam dilectissimam non honorare. Atque, cum eam posset tam magne honore exornare, ut eam a sepulcri corruptione servaret incolumem, id reapse fecisse credendum est.

Maxime autem illud memorandum est, inde a saeculo II, Mariam Virginem a Sanctis Patribus veluti novam Hevam proponi novo Adae, etsi subiectam, arctissime coniunctam in certamine illo adversus inferorum hostem, quod, quemadmodum in protoevangelio (Gn. 3, 15) praesignificatur, ad plenissimam deventurum erat victoriam de peccato ac de morte, quae semper in gentium Apostoliscriptis inter se copulantur (Rom. cap 5 et 6; 1 Cor. 15, 21-16; 54-57). Quamobrem, sicut gloriosa Christi anastasis essentialis pars fuit ac postremum huius victoriae tropaeum, ita Beatae Virginis commune cum Filio suo certamen virgine corporis, ,glorificatione" concludendum erat; ut enim idem Apostolus ait, „cum ... mortale hoc induerit immortalitatem, tunc fiet sermo, qui scriptus est: absorpta est mors in victoria. (1 Cor. 15,54).

Idcirco augusta Dei Mater, Iesu Christo, inde ab omni aeternitate, „uno eodemque, decreto praedestinationis, arcano modo coniuncta immaculata in suo conseptu, in divina maternitate sua integerrima virgo, generosa Divini Redemptoris socia, qui plenum de peccato eiusque consectariis deportavit triumphum, id tandem assecuta est, quasi supremam suorum privilegiorum coronam, ut a sepulcri corrutione servaretur immunis, utque, quemadmodum iam Filius suus, devicta morte, corpore et anima ad supernam Caeli gloriam veheretur, ubi Regina refulgeret ad eiusdem sui Filii dexteram, immortalis saeculorum Regis (1 Tim. 1,17). 
Quoniam igitur universa Ecclesia, inqua viget Veritatis Spiritus, qui quidem eam ad revelatarum perficiendam veritatum cognitionem infallibiliter dirigit, multipliciter per saeculorum decursum suam fidem manifestavit, et quoniam universi terrarum orbis Episcopi prope unanima consensione petunt, ut tunquam divinae et catholicae fidei dogma definiatur veritas corporeae Assumptionis Beatissimae Virginis Mariae in Caelum - quae veritas Sacris Literis innititur, christifidelium animis penitus est insita, ecclesiastico culto inde ab antiquissimis temporibus comprobata, ceteris revelatis veritatibus summe consona, theologorum studio, scientia ac sapientia plendide explicata et declarata - momentum Providentis Dei consilio praestitutum iam advenisse putamus, quo insigne eiusmodi Mariae Virginis privilegium sollemniter renuntiemus.

Quapropter, postquam supplices etiam atque etiam ad Deum admovimus preces, ac veritatis Spiritus lumen invicavimus ad Omnipotentis Dei gloriam, qui peculiarem benevolentiam suam Mariae Virgini dilargitus est, ad sui Filii honorem, immortalis saeculorum Regis ac peccati mortisque victoris, ad eiusdem augustae Matris augendam gloriam et ad totius Ecclesiae gaudium exsultationemque.

Auctoritate Domini Nostri Iesu Christi, Beatorum Apostolorum Petri et Pauli ac Nostra pronuntiamus, declaramus et definimus revelatum dogma esse: Immaculatam Deiparam semper Virginem Mariam, expleto terrestris vitae cursu, fuisse corpore et anima ad caelestem gloriam assumptam.

Quamobrem, si quis quod Deus avertat, id vel negare, vel in dubium vocare voluntarie ausus fuerit, quod a Nobis definitum est, noverit se a divina ac catholica fide prorsus deficisse.

VERTALING: ,Al hierdie argumente en denke van die heilige vaders en teoloë berus op die Heilige Skrif asof op die diepste grond, en hierdie dinge hou aan ons voor - asof voor ons oë die goedhartige moeder van God; sy is in noue verband met haar goddelike Seun en het altyd deel aan Sy lot. Om hierdie rede lyk dit feitlik onmoontlik om haar wat Christus ontvang het, aan Hom geboorte geskenk het, met haar melk gevoed het en Hom in haar arms gehou het asook aan haar bors vasgedruk het, te skei van Hom, wat na haar lewe op hierdie aarde, ofskoon in liggaam van Hom geskei, maar tog nie in gees nie. Aangesien ons Verlosser die seun van Maria is, kon Hy, aangesien Hy die mees onberispelike Houer van die goddelike wette is, inderdaad nie anders as om ook sy mees geliefde moeder, bo en behalwe die Ewige Vader, te eer nie.

Nou, aangesien dit moontlik was $\mathrm{cm}$ haar op so 'n grootse wyse te vereer deur haar te red van die verderf van die graf, moet dit geglo word dat Hy dit wel gedoen het. 
Dit moet egter beklemtoon word dat alreeds vanaf die tweede eeu, die maagd Maria deur die heilige vaders voorgehou is as 'n nuwe Eva by 'n nuwe Adam; alhoewel ondergeskik, is sy daadwerklik verbind in daardie stryd teen die vyand van die onderwêreld, 'n stryd wat, soos in die protoevangelie aangekondig word, sou uitloop op 'n volkome oorwinning wat betref die sonde en die doood, twee dinge wat altyd met mekaar verbind word in die boek van die apostel van die heidene. Om hierdie rede, soos die verheerlikte opstanding van Christus 'n essensiële deel was, asook die laaste teken van hierdie oorwinning, so moes die gesamentlike stryd van die geseënde maagd en haar Seun, afgesluit word met die verheerliking van haar maagdelike liggaam, want soos dieselfde apostel sê: „Wanneer hierdie verganklike met onverganklikheid beklee is, dan sal vervul word die woord wat geskrywe is: die dood is verslind in die oorwinning."

Daarom het die heilige moeder van God, wat van alle ewigheid verenig is met Jesus Christus, op 'n misterievolle wyse deur die raad (besluit van die verkiesing, onbevlek in haar ontvangenis, onbevlek in haar goddelike moederskap, die goedhartige bondgenote van die Verlosser wat 'n volledige triomf gevier het oor die sonde en sy gevolge; het sy eindelik bereik, asof dit die hoogste kroon van al haar voorregte was, dat sy behoue bewaar is van die verderf van die graf en dat sy dus, net soos haar Seun recds, met liggaam en gees, nadat die dood oorwin is, weggeneem is na die hoogste heerlikheid van die Hemel, waar sy daar as Koningin kan skitter aan die regterhand van haar Seun, die onssterflike Koning van alle eeue.

Aangesien dan die hele Kerk, waarin die Gees van Waarheid leef, wat haar inderdaad onfeilbaar lei tot vervolmaking van die kennis van die geopenbaarde waarhede, menigvuldiglik deur die loop van die eeue haar geloof getoon het, en aangesien die biskoppe van die hele wêreld daarna vra met byna eenstemmige opinie, dat dan eindelik die waarheid van die liggaamlike opneming van die heilige maagd Maria in die hemel, as dogma van die heilige katolieke geloof definieer kan word - 'n waarheid wat berus op die Heilige Skrif en vasgewortel is in die harte (gemoedere) van die christengelowiges, wat deur die liturgie van die Kerk van vroegste tye her gesanksioneer is en die hoogste mate ooreenstem met alle ander geopenbaarde waarhede, en deur die studie, kennis en wysheid van die teoloë uitstekend ontplooi en verklaar is - dink ons dat die oomblik, aangewys deur die raad van die voorsienigheid van God nou aangebreek het om op plegtige wyse die heerlike voorreg van dieselfde maagd Maria aan te kondig. Daarom, nadat ons herhaalde kere ons smeekgebede tot God gerig het, het ons ook die lig van die Gees van Waarheid aangeroep tot die eer van die Almagtige God, wat Sy buiten- 
gewone welwillendheid rykelik aan die maagd Maria uitgedeel het - en dit tot eer van Sy Seun, die onsterflike Koning van alle geslagte, die oorwinnaar van die sonde $\mathrm{en}$ die dood - om die eer van die heilige moeder te vermeerder en tot die blydskap en vreugde van die hele Kerk.

Op gesag van onse Heer, Jesus Christus, van die heilige apostels Petrus en Paulus en op ons gesag, kondig ons aan, verklaar en omskryf ons dat dit as dogma openbaar is, naamlik dat die onbevlekte moeder van God, Maria-altyd-maagd na voltooiing van haar lewe op aarde, met liggaam en siel na hemelse glorie opgeneem is.

Om hierdie rede, as iemand uit eie beweging sou waag om dit of te ontken of in twyfel te trek wat deur ons bepaal is, (mag God dit verhoed) laat hy dan weet dat hy dadelik van die heilige katolieke geloof afgewyk het."

\section{B. Die Roomskatolieke Verklaring van hierdie Ewolusie.}

Die dogmenhistoriese lyn in die vorige paragraaf dui op die waarheid van HARNACK se bewering: „Man darf in mancher Beziehung sagen, was die Arianer van Christus gelehrt hatten, das lehrten die Orthodoxen jetzt von Maria; sie ist die halbgöttische Vermittlerin zwischen Gott und Menschen." ${ }^{22}$ )

Die Roomskaolieke Kerk staan hier dus gekonfronteer met 'n dubbele probleem; 'n formele en materiële probleem:

(a) FORMEEL: Rome sê: Roma semper eaden est. Hoe moet die ontwikkeling in die lig van hierdie tipies Roomskatolieke grondstelling verstaan word? Is Rome altyd dieselfde? Hoe kan BARTMANN praat van die wesenlike „Unveränderlichkeit und Indefektibilität der Glaubenslehre", ${ }^{25}$ ) in die lig van hierdie ononbetwisbare uitbreiding? Ons sal straks die verskillende verklaringe moet nagaan, waardeer en kritiseer.

(b) MATERIEEL: Op grond van welke Bybelse of ander gegewens regverdig die Roomskatolieke Kerk die inhoud van hierdie uitbreidinge? Hoe regverdig die Roomskatolieke Kerk die beroep op hierdie ander gegewens (die tradisie) as tweede openbaringsbron naas die Heilige Skrif?

\section{DIE FORMELE PROBLEEM:}

(1) DIE TÚBINGERSKOOL. J. A. Möhler. (1796-1838)).

Hierdie skool het ontstaan in die tyd van die Romantiek met sy hoofgedagte: organisme en ontwikkeling. In die geskiedenis van die Christendom is naamlik 'n organiese ewolusie te bespeur. MöHLER wys veral na die dwaalleringe as oorsaak van

22) A. von Harnack: Lehrbuch II, bls. 477

23) B. Bartmann: Lehrbuch der Do'matik I, bls. 65. 6de Druk. Uitg. Herder en Kie. Verlagsbuchhandlung, Freiburg, 1923. 
die ontwikkeling van die Kerkleer. Nadat 'n nuwe dwaallering opgekom het, is die situasie gewoonlik gewysig en moet dieselfde openbaringswerklikheid op andere wyses uitgedruk word. Die ewalusie van die dogma is ' $n$ innerlike organiese ,in Gegensätzen fortschreitende Entwicklung". ${ }^{2+}$ Die „bewussyn" van die Kerk was gedurende al die eeue betrokke op dieselfde openbaringswerklikheid van die Inkarnasie. Die verskil in die weergawe van die openbaarde waarheid is te verklaar uit die aanpassing aan die historiese situasie. Daar is geen nuwe openbaringe nie. 'n Christelike leerstuk van vandag, moet in sy „kiem" in die Kerk steeds aanwesig gewees het. Die "terminus ad quem" is reeds in die "terminus a quo" opgesluit. Die homogeniteit van die dogmaontwikkeling is gewaarborg deur die onfeilbaarheid van die Kerk op grond van die feit dat die Heilige Gees aan die Kerk gegee is. Die Kerk kan die Skrif interpreteer op dogmatiese wyse, d.w.s. met die Heilige Gees as uitlegginsprinsiep.

(2) J. H. NEWMAN (1801-1890) ${ }^{25}$ ). In sy werk „An Essay on the Development of Christian Doctrine", (1845) kom sy gedagtes baie ooreen met Tübingerskool. Ook hy wil uitgaan van 'n openbaring wat in die apostoliese tyd afgesluit is, Die Kerk moet in sy ontwikkeling van die dogma, van die apostoliese getuienis van die openbaring uitgaan. 'n Suiwer dogmatiese proses is alleen in die Roomskatolieke Kerk te vind, waar die Heilige Gees werksaam is en die leergesag onfeilbaar maak.

Tradisie beteken in die eerste plek, dat van geslag tot geslag dieselfde openbaringswerklikheid leef in die onbewuste "sensus" van die Kerk. Die ,intuĩsie" wat hierdie werklikheid aanvul, is 'n geloofsintuīsie. Die leergesag van die apostoliese prediking word nie slegs stereotiep herhaal nie, maar dit ontwikkel al na gelang die aktualiteit van die situasie. Tradisie beteken ook: Die apostels het meer verkondig as wat in die Nuwe Testament opgesluit is; hierdie ,plus" is deur die oorlewering van die Roomskatolieke Kerk bewaar. Die tradisie het dus ook 'n bewarende funksie. Die ontwikkeling van die dogma is soos die ontwikkeling van 'n „,idee", wat een en dieselfde kan bly onder verskillende uiterlike gestaltes, solank dit voortdurend deur dieselfde beginsel gelei word. Wat in die loop van die ontwikkeling vorm aanneem, is reeds in die begin aanwesig.

24) J. A. Möhler: „Symbolik . ." gesiteer deur Dr. G. Meuleman. A.W. bis. 12 , vgl ook BARTMANN: A.W. 1, bls. 67 .

25) Dr. G. E. Meuleman. De Ontwikkeling van het Dogma in de Roomskatholieke Theologie. Dissertasie. Uitg. J.H. Kok, Kampen 1951. Bls. 15-23. Vgl. ook Bartmann: A.W., bis. 67.

26) Dr. G. E. Meuleman. A.W. bls. 23 en Bartmann: A.W. I, bls. 65.

27) Denzinger: A.W. No. 1619. 
(3) DIE MODERNISTIESE OPVATTING ${ }^{26}$ ). In 1835 het die Roomskatolieke Kerk die dwaalleer van HERMES veroordeel ${ }^{27}$ ). Onder invloed van KANT het HERMES geleer dat mens met sy verstand die waarheid van die geopenbaarde dogma moet bewys om van sy inhoud seker te wees. Verskillende ander rasionalisties-modernistiese opvattinge wat onderling varieer, is deur die Vatikaanse Konsilie veroordeel.

Teenoor die modernisme leer die Vatikaanse konsilie:- dat die Roomskatolieke Kerk nooit onder invloed van 'n onhoudbare of verouderde filosofie tot uitsprake gekom het nie. Hinc sacrorum quoque dogmatum is sensus perpetuo est retinendus quem semel declaravit sancta Mater Ecclesia, nec unquam ab eo sensu altioris intelligentiae specie et nomine recedendum ${ }^{2 *}$ ). Nuwe dogmatiese formuleringe is volgens die Vatikaanse Konsilie moontlik, maar nie nuwe openbaringe na die dood van die apostels nie. Die Kerk moet sorg dat die leer van Christus "sincera et pura" bewaar word. Aan die opvolgers van Petrus is die Heilige Gees beloof, nie om ,eo revelante" 'n nuwe leer te gee nie, maar om „eo assistente" die deur die apostels oorgelewerde geloofsdepositum te bewaar en te verklaar. By die vervulling van hierdie taak bly die stoel van Petrus ,ab omni semper errore illibata”, volgens Lukas 22 v. 32 . Die Konsilie veroordeel enige substansiële groei van die dogma. Aan die begin van die ontwikkeling staan die Skrif en Apostoliese tradisie, waarvan die inhoud ook die grense van die ewolusie bepaal'?).

(4) DIALEKTIESE OPVATTING VAN DOGMA ONTWIKKELING: ${ }^{30}$ )

Hierdie bewoording, "dialekties", het nie iets met HEGEL te doen nie. Dit word gebruik omdat dit in die Roomskatolieke teologie die gangbare aanduiding is van die skolastieke teorieë oor die dogma-ontwikkeling.

Ook FRANZELIN sien aan die begin van die dogmatiese proses die afgeslote openbaring. Die wettigheid van die dogmaontwikkeling is "dialekties" d.w.s. met behulp van sluitredes, te bewys. Die hele dogma-ontwikkeling bestaan hierin dat die Kerk langsaam eksplisiet kan ken wat die apostels ook eksplisiet geweet het maar minder duidelik meegedeel het. Die ontwikkeling ontstaan deur: ${ }^{31}$ ).

(a) explicatio van die implisiete.

(b) wat vroeër meer bedek geleer is, word in die latere tye meer duidelik geleer.

28) Meuleman: A.W. bls. 28 en Bartmann, A.W. I, bls. 65.

29) Meuleman: bls. 29 (A.W.)

ao) Meuleman: A.W. bls. 31-35.

31) Meuleman: A.W. bls. 32. 
(c) die Kerk hou die leerstukke voortaan meer „distincte” voor aan die gelowiges. stadia:

By die groei van die dogma onderskei FRANZELIN ${ }^{32}$ ) drie

(1) Aanvanklik word 'n leerstuk implisiet bely, algemeen en prakties gehandhaaf, totdat 'n kontrovers ontstaan.

(2) Daarna word die leer ondersoek en lei die Heilige Gees die leergesag op direkte wyse, en hulle wat die leergesag dien in die voorbereiding om tot uitspraak te kom, op indirekte wyse tot helderheid.

(3) Dan word die dogma gedefinieer. Die menslike element speel hier sy rol aangesien die arbeid van die Heilige Gees beperk is tot .,assistensie". Dat die uitspraak onfeilbaar is hang volkome af van die beloofde goddelike bystand.

\section{(5) DIE „TEOLOGIESE” OPVATTING VAN DOGMA ONTWIK- KELING.}

Hierdie rigting wys veral op die bowenatuurlike karakter van dogma-ontwikkeling. Die vasstelling van die homogeniteit van die dogma-ontwikkeling is nie vir die natuurlike verstand moontlik nie. Nie die menslike logika nie, maar die goddelike Wysheid het die leiding in die leer-ontwikkeling. Dogma ontwikkeling is nie 'n logiese nie maar 'n Theo-logiese proses. ${ }^{33}$ )

Maurice BLONDEL (1861-1949): Die taak van die tradisie is baie ruim op te vat; dit is nie slegs die oorlewering van wat vroeër formeel gedink en uitgedruk is nie. Waarhede wat vroeër uitdruklik meegedeel is, word dikwels eers later begryp nadat dit vir 'n lang tyd in die onderbewuste bly lewe en ontkiem het. Die tradisie bewaar uit die verlede nie so seer die intellektuele aspek nie, maar wel die vitale realiteit. Die tradisie ontdek en formuleer die waarhede waarvan die verlede geleef het, sonder om dit eksplisiet te kan definieer. Die tradisie gee aan die Kerk die outoriteit ten aansien van die Skrif. ${ }^{34}$ )

Die verskil tussen BLONDEL en die dialektici i.v.m. die dogma-ontwikkeling bestaan veral daarin, dat volgens lg. opvatting, die hele waarheid, wat deur die Kerk in sy dogma gedefinieer word, in die apostoliese tyd reeds in begryplike vorm uitgedruk is, dat alleen die kennis van die begryplike uitdrukking uit die tyd, op sigself beskou, al voldoende is om die teenwoordige dogma af te lei en te regverdig. ${ }^{35}$ )

32) Meuleman: A.W. bls. 32. Vgl. i.v.m. Franzelin ook Bartmann, A.W. I, bls. 68.

33) C. E. Meuleman, A.W. bls. 51

34) C. E. Meuleman, A.W. bls. 61-62

35) C. E. Meuleman, A.W. bls. 63. 


\section{DIE ROOMS-KATOLIEKE REGVERDIGING VAN DIE MA- RIOLOGIESE DOGMA-ONTWIKKELING:}

Die ewolusie van die dogma staan volgens die R.K. Kerk nie in stryd met sy onveranderlike karakter nie; die uitbreiding deur die eeue is slegs 'n „uitstraling" van die volle rykdom van die onveranderlike dogma" waarvan die substansie onveranderd bly. In die Mariologie word die groeiproses duidelik geillustreer. Die leer van die onbevlekte ontvangenis van Maria, het volgens die Roomskatolieke Kerk reeds beslote gelê in die goddelike openbaring, soos 'n „blom wat nog in sy knop was." In die taal van die Tübingerskool met sy hoofgedagte van organisme en ontwikkeling is dit so te sien: Langsamerhand het hierdie „blom" oopgegaan en is die insig verdiep en verryk. Na eeue het die Heilige Gees „de aandacht der geloovigen gaat richten op den oorsprong zijner bruid, en dan gaan de onbevlekte ontvangenis zich losmaken uit het geheel der Mariologische waarheden om dan ten volle te worden gekend en verstaan." ${ }^{36}$ ) Alhoewel verset gekom het, het die Heilige Gees voortgegaan met die werk wat Hy begin het, sodat die oortuiging van die ,immaculata conceptio" steeds dieper gegroei het totdat die teenstand van rede en wetenskap oorwin is, omdat die Kerk met onfeilbare leergesag hierdie heerlike waarheid kon afkondig as „dogma formale" (1854). In 1854 het die pous ,,aan die Kerk nie iets nuuts geleer nie, maar ,iets ouds op nuwe wyse", nl. op onfeilbare wyse." ${ }^{37}$ Sedert 1854 ,ist Maria im Organismus des katolischen Glaubens und Lebens in immer helleres Licht getreten . . Seit der Definition der unbefleckten Empfängnis geht eine marianische Welle durch die katolische Welt ... ein marianischer Frühlung in Gottes Kirche". ${ }^{38}$ )

Die Roomskatolieke dogmatikus, M. J. SCHEEBEN, is van mening dat die onbevlekte ontvangenis in beginsel (in embryo) reeds opgesluit is in die groet van die engel, „plena gratia”. SCHEEBEN noteer by Gen. 3 v. 15 en die groet van die engel: „dasz der undbefleckte Ursprung mariens nothwendig darin eingeschlossen ist und zwar nicht blosz als theologiche Conce quenz, sondern als zur Vollständigkeit des unmittelbaren Inhalts gehörig". ${ }^{39}$ )

36) Dr. G. C. Berkouwer sitaat uit J. Kersten: Het dogma der onbevlekte en ontvangenis van Maria (De stryd om het Roomskatolieke Dogma, J. H. Kok. Kampen bls. 179.)

3i) G. Friethoff: „Katholieke Marialeer" Art. in serie „Waarheld en Leven” 1937, bls. 52, siteer deur Berkouwer: De Stryd om het Rooms-Katolieke Dogma, bls. 179.

$\left.{ }^{32}\right)$ F'. Kastner: ,Marianische Christusgestaltung der Welt", 1936, bls. 295-296 gesiteer deur Berkouwer: De Stryd om het Rooms-Katolieke Dogma, bls. 180.

38) M. J. Scheeben: Handbuch der Katholischen Dogmatik, Freiburg 1948, bls. 539 . 
Die ontwikkeling van die mariologiese dogma is dus vir die Roomskatoliek volkome gewettig solank die, volgens Rome se beskrywing, valse opvatting uitgesluit worc', nl. die valse opvatting as sou die ontwikkeling die waarheid van die Openbaring wesenlik (subsansieel) verander, of as sou die ontwikkeling 'n nuwe openbaring beteken ${ }^{40}$ ). Teenoor die valse opvatting van die ewolusieproses, staan „Der wahre dogmatische Fortschritt”: „Es gibt somit keine substantielle Veränderung des Dogmas, keine absoluten Fortschritt im Dogma; aber es gibt einen aksidentellen, relativen dogmatische Forftschritt, der darin besteht, dass die Kirche die Warheiten des depositum fidei immer tiefer und genauer kennenlernt, immer besser erklärt und in immer volkommeneren und verständlicheren Formeln ausspricht und vorlegt"'11).

Uit bostaande moet ons tot die gevolgtrekking kom dat die Roomskatolieke kerk alle ewolusie of uitbreiding wat 'n verandering in die substansie of wese van die dogma (dogma-is-gelykaan-openbaring-is-gelyk-aan-,,Glaubenslehre”) wil aanbring, met die sterkste nadruk afwys, soos die Vatikaanse Konsilie die rasionalistiese teorieë inderdaad veroordeel het ${ }^{+2}$ ). Word die vraag aan die Roomskatolieke kerk gestel, watter gronde aangewys kan word om hierdie ,aksidentele”, relatiewe „Fortschritt" te regverdig, welke sekerheid daar bestaan dat die ontvouing van die dogma deur die eeue nie verstrik geraak het (voor 1870) in dwaalleringe nie, dan sal die antwoord ondubbelsinnig lui:-

(a) "Der in der Kirche waltende heilige Geist soll in alle Wahrheit einführen." ${ }^{+3}$ (Joh. 6 v. 13).

(b) Ontvouing van die dogma is vanselfsprekend noodwendig wanneer die kerk sy „damnatus" laat hoor teenoor die dwaalleringe. Reeds die patres het in hulle stryd teen die ketters meegewerk aan die ontvouing van die dogma.

(c) Die arbeid van teoloë afsonderlik en gesamentlik, dit wil sê, „Jeder Kundige weiss wie durch einzelne Koryphäen und Schulen der wissenschaftliche Fortschritt gefördert worden ist. Man denke an Athanasius, Augustin, die Scholastik und das Tridentinum".

40) B. Bartmann: Lehrbuch der Dogmatik, I. bis. 65:- " . . als wenn dieser Fortschritt eine substantielle Verandering der Wahrheit. eine Fortsetzung der Offenbarung bedeute; diesen Irrtum wird die Erklärung von der wesentlichen Unveränderlichkeit und Indefektibilität der Glaubenslehre entgegengesetzt."

41) B. Bartmann: A.W., I, bls. 65.

42) Denzinger: A.W. 1619 en Bartmann A.W., I, bls. 65.

43) Bartmann: A.W. I, bls. 66. 
(d) Reeds Paulus en Johannes het in hulle prediking so 'n uitbreiding in die geloofsbelydenis teweeggebring. BARTMANN verwys na $I$ Kor. 2 v. 6-16, 3v. 1v.v., Efese 1 v. 17-19, 3v. 3v.v., 3v. 18v.v., 5v. 9-14v.v., vgl. ook Johannes 1v. $\left.1-14 .{ }^{44}\right)$

\section{DIE SIN EN BETEKENIS VAN DIE PARTHENOGENESIS VOLGENS DIE ROOMSKATOLIEKE KERK.}

Ons het langs dogmenhistoriese lyn die "wortels" van die Roomskatolieke mariologiese dogmata kortliks aangetoon. Ons het ook die uitbreiding of "ewolusie" van hierdie dogmata nagegaan, die R.K.regverdiging daarvan in oënskou geneem.

Ons kom nou tot die vasstelling van die dogmatiese betekenis van die parthenogenesis volgens Rome. Aan die hand van die R.K. dogmatiese handboeke blyk dat die volgende aspekte vir ons ondersoek van belang sal wees: ${ }^{45}$ ).

Geloof as dogma-geloof. Die gesag van die Apostolicum as tradisie-dokument en vandaar-uit te verstaan die aanspraak van Art. III van die Apostolicum betreffende die parthenogenesis.

Die sin en betekenis van hierdie dogma in die besonder, veral ten opsigte van:

Maria as (a) Medeverlosseres, en (b)Middelares. (c) Maria in haar perpetuele virginiteit: Die virginiteit as etiese ideaal.

(d) Maria as Hemelkoningin. Haar hemelvaart.

\section{Geloof as Dogma-geloof:-}

Geloof is vir die Roomskatoliek wesenlik doma-geloof; dogma is vir hom wesenlik ,te-geloven-dogma"; die sin van die dogma vir die Roomskatoliek is dieselfde as wat die leer van Christus vir die geloof van sy apostels beteken het: „noodsaaklike en wesenlike en enige weg en waarheid en lewe waarlangs en waarin en waardeur hulle geloof God self, Sy waarheid en Lewe gevind het"..66).

Wat beteken „,dogma” in die Roomskatolieke sin?:- „Everything revealed by God, or Christ, or the Holy Ghost is by that very fact a Divine or Christian Dogma; when authoratively proposed by the apostels it became an Apostolic dogma; when fully promulgated by the Church, Eecclesiastical Dogma. In the Church's language a dogma pure and simple is at the same time

44) Bartmann: A.W. I, bls. 67.

45) Ons gebruik veral die werke van B. Bartmann, M. J. Scheeben, H. Denzinger, „De Katholieke Kerk" (3 dele) onder redaksie van Prof. D. Bont en Dr. C. F. Pauwels, verder: J. Wilhelm en T. B. Scannell: „A Manual of Catholic Theology", G. D. Smith: "Mary's Part in our Redemption", e.a.

46) F. Malmberg: S.J. ..De Betekenis van het dogma voor het geloof" in „Vox Theologica”, Maart 1951, bls. 97 en 98. 
ecclesiastical, apostolic and Divine. But a merely Divine Dogma - that is, revealed by God but not yet explicitly proposed by th Church - is called a Material (as opposed to Formal Dogma"si $)$.

Ook BARTMANN gee die begrip ,dogma” soos volg aan:„Dogma (dogma catholicum) ist jede religiöse Wahrheit, welche von Gott übernaturlich geoffenbart ist und von der Kirche als solche zu glauben vorgelegt wird. Zwei Wesens-merkmale trägt also jedes Katolische Dogma: ein inneres, sachliches, das Enthaltensein in der Offenbarung, und ein äusseres, júridisches, die Verkündigung durch die Kirche. ${ }^{48}$ )

SMITH sê: „What the Church, therefore, teaches as divinely revealed, that most certainly is revealed by God and must be believed on the divine authority. These truths, revealed by God, i.e. contained in Tradition or in Scripture, or in both, and taught by the Church either in her solemn definitions or in her ordinary teaching - are called by the technical name of dogmas"..${ }^{94}$ )

Uit bostaande definisies is dit duidelik dat die twee wensenskenmerke van die Roomskatolieke dogma is:-

(a) Dat dit besluit is in die Openbaring van God.

(b) Dat dit afgekondig word deur die Roomskatolieke kerk.

Die Roomskatolieke sin en betekenis van die dogma word bepaal deur dit wat die dogma in wese is „Das Dogma ist nicht rein symbolischer Art, sondern hat wirklichen Erkenntniswert; es ist nicht zunächts Sittenregel, sondern Glaubensnorm wenngleich sein indirekter Einfluss auch auf das sittlische Leben gross ist." ${ }^{50}$ ) Dit hang verder saam met die betekenis van die Kerk en kerklike leergesag: deur die getuies van die Heilige Gees glo mens in vitale verbondenheid tussen die menslike draers van die deur Christus self ingestelde leergesag en die verheerlikte Heiland aan Sy Regterhand. Daarom is die dogma vir die Roomskatoliek „,niet alleen kwestie van een heilige geloofsplicht, van een moeten gelooven in de leer die het onfeilbaar magisterium der Kerk als dogma voorhoudt, maar boveal van een liefdevol en dankbaar en blijde mogen gelooven in de Zelfopenbaring van God onze Vader . . . Met de ogen des geloofs vermogen wij het

47) J. Wilhelm en T. B. Scannell: „A Manual of Catholic Theology" ,based on Scheebens „Dogmatik" ", London and New York, 1909. Deel I, bls. 88.

48) Dr. B. Bartmann: „Lehrbuch der Dogmatik”, Sechte Auflage 1923. Erster Band, bls. 4." (Uitg. Herder \& Co. Verlagsbuchhandlung, Freiburg im Breisgau).

49) Rev. G. D. Smith, D.D. Ph.D.: Art. „Faith and Revealed Truth” in "Teaching of the Catholic Church", A Summary of Catholic Doctrine arranged and edited by G. D. Smith. Vol. I, bls. 31. Uitg. Burns Oates \& Washbourne, London 1948.

50) Bartmann: A.W. I, bis. 6. 
te zien als delend in het gezag van de zich openbarende God, als geloofsgehoorsaamheid en geloofsaanvaarding van ons vorderend. Het dogma is voor de tot geloven begenadigde mens, zelf geloofswaardigheidsmotief." ${ }^{51}$ ) Die geloofwaardigheid van die dogma berus daarin dat die gesag van die openbarende God daarin verskyn.

MALMBERG het die sin van die Roomskatolieke dogma onder die volgende gesigspunte saamgevat: ${ }^{5^{2}}$ )

(1) 'n Dogma is 'n deur God in Jesus Christus geopenbaarde leerstelling en daarom 'n leerstelling van die christelike leer.

(2) In die geloofsaanvaarding van die dogma, ontmoet die mens, uit die krag van die genade van God, persoonlik en onmiddellik, die tot hom sprekende en openbarende God. In ons historiese heilsbestel, waarin God werklik mens geword het, gedink het in menslike begrippe en gepraat het in menslike taal, is die dogma die ,enigste weg" tot die persoonlike en onmiddellike geloofskontak.

(3) Die leergesag van die Kerk van Christus, onfeilbaar deur die blywende bystand van die Heilige Gees van Christus, is alleen in staat om aan ons die dogma aktueel voor te hou om geglo te word d.m.v. die leerorgane van sy mistieke liggaam, en verklaar vir ons aktueel wat daar vervat is in die eertyds deur Hom geopenbaarde en aan sy Kerk toevertroude geloofskat.

(4) Die "nuwe" formulering voeg derhalwe niks toe aan die onveranderlike geloofskat nie, maar dit dui op die onuitputlike rykdom van die christelike Openbaring waarna die Kerk van Christus hier benede altyd moet uitkyk en wat die Heer voortdurend deur Sy Heilige Gees aan Sy Kerk wil verklaar.

(5) Die dogma dui ook op die "geheimenis" wat die Openbaring van God in die dogma self, noodsaaklik omhul. Hoe onmiddellik my geloofskontak met „my Here en my God" (Joh. 20 vers 28 ) in die Dogma ook is, dit by hier benede 'n sien „deur 'n spiëel in 'n raaisel", (1 Kor. 13) en is nog geen ,aanskouing van aangesig tot aangesig" nie.

(6) As menslike uitdrukking van die waarheid van God het die dogma „deel aan die gesag van die openbarende God." Om hierdie rede is dit vasomskrewe, apodikties en duld geen teenspraak nie. Buitekant die vasomlynde dogma is die dwaling.

Wat die betekenis van die „Apostolicum" in die Roomskatolieke Kerk betref, is dit al dadelik opvallend dat hierdie geloofbelydenis voorop staan. Reeds in die tweede hoofstuk van die

51) F. Malmberg: Art. ..De Betekenis van het Dogma voor het geloof" in „Vox Theologica”, Maart 1951, bls. 100.

52) F. Malmberg: Aangehaalde Artikel in „Vox Theologica” Maart 1951, bls. 102-103. 
Catechismus Romanus begin die uitleg van die Apostolicum ${ }^{\text {33). }}$. In die liturgie het dit 'n vername plek; dit staan onder die opskrif „Daaglikse gebede en oefeninge." Die Roomskatolieke lidmaat moet dit daagliks bid; die priester herhaal dit daagliks. By twee sakramente, t.w. doopsel en priesterwyding het dit sy plek in die liturgie ${ }^{5 s}$ ).

P. SCHOONENBERG ${ }^{55}$ ) in sy waardering van die Apostolicum, wys daarop dat die gesag wat die Apostolicum in die Roomskatolieke kerk beklee, af te lei is uit die feit dat dit 'n tradisiedokument is. Die konsilie van Trente het vasgestel: dat daar behalwe die Skrifte ook apostoliese oorleweringe bestaan wat tot ons gekom het; dat die heilige Kerk hierdie oorleweringe tesame met die boeke van die Ou en Nuwe Testament met gelyke liefde en eerbied aanvaar en vereer. (Denz 783). Vir die Roomskatoliek is daar geen enkele oorlewering wat nie in die Skrif sy „aanknopingspunte en kieme" het nie, soos daar ook geen enkele Bybelse leer is wat nie vra „om door de overlevering te worden geinterpreteerd." So 'n tradisie-dokument is die apostolicum. Die Apostolicum is 'n sterk neerslag van die vroegste tradisie. Ook hierdie tradisie kry sy betekenis uit sy gesag: „Want vooreerst kan traditie of overlevering zo begrepen worden dat zij mede de Schriften insluit: Ook die immers worden ons door de apostelen en de na hen komende generaties overgeleverd. Maar ook wanneer in meer beperkt zin onder overlevering alleen verstaan wordt niet onder apostolischen gezag in de Schriften vastgelegde erfgoed dat de Kerk tog van deapostelen besit, (waarom zij dan ook mondelinge of ongeschreven overlevering genoemd wordt) ook in dit geval blyft nog by het onderscheid tussen Bijbəl en traditie, een binding en samevallen geensins uitgesloten".; )

Die geskiedenis en voorgeskiedenis van die Apostolicum bewys vir die Roomskatoliek dat die christelike geloof nooit bestaan het sonder 'n geformuleerde belydenis nie. Hierdie noodsaaklikheid van die belydenisformule vir die geloofsdaad bring mee dat ook die belydenisformule 'n verpligtende karakter dra. Die Roomskatolieke Kerk hou die Apostolicum om hierdie rede voor met leergesag, nie deur 'n dogmatiese uitspraak van die pous of ' $n$ algemene konsilie nie, maar deur die „magisterium ordinarium et universale", d.w.s. deur die leer van die Roomskatolieke episkopaat oor die hele aarde ${ }^{57}$ ).

53) Cathechismus er Decreto Concillii Tridentini ad Parochos 1921.

54) P. Schoonenberg: Art. „De Apost. Geloofsbelijd. in de Kath. Kerk.”, in die bundel: ..Geloofsinhud en Geloofsbeleven", ,.Een peiling binnen Reformatie en "Katholieke Kerk in Nederland"'. onder redaksie van Dr. H. v. d. Linde en Dr. F. Thyssen. Uitg. Het Spectrum, Utrecht, 1951 , bls. 146 .

5i) P. Schoonenberg: A.W., bls. 148-149.

56) P. Schoonenberg: Aangehaalde artikel bls. 149.

5i) P. Schoonenberg: Aangehaalde artikel bls. 149. 
Die Roomskatolieke sin en betekenis van die dogma van die parthenogenesis in die besonder, word geilllustreer deur die voortgaande ontwikkeling van die leer van Maria. Ons dogmenhistoriese ondersoek het die uitbreiding van die leer aangaande die persoon en funksie van Maria aangetoon, sodat ons slegs 'n insig moet kry in die uitkoms van genoemde ondersoek: Wat is tans die sin en betekenis van Maria in die Roomskatolieke Dogmatiek? BARTMANN verklaar ${ }^{58}$ ): „Zweifach ist die Bedeutung der Heiligen Jungfrau: Objektiv: weil sie uns den Welterlöser geboren hat und dadurch universo generi humano causa facta est salutis, (Irenaeus Adv. H. 3, 22, 4) und subjektiv, weil sie uns das leuchtendste Beispiel stiller, innerer Christentugend gegeben hat.

Und wenn Ambrosius sagt: „Empfängnis und Geburt eines Heiligen bedeutet nicht nur Gnade für die Eltern, sondern auch Heil für Tausend andere, (Lukaskommentar, 1,29) so gilt das doppelt von der allerseligsten Jungfrau Maria" . . . In Predigt und Katechese sollten wir nich vergessen, an die Darstellung des Gnadenstandes Mariens die des Mitwirkens und Lebens stets anzuschliessen, damit ihre Tugend nicht nur leuchtet, sondern auch anzieht."

Die dogma-ontwikkeling het gelei tot die punt waar 'n diskussie ontstaan het tussen die Roomskatolieke teoloë onderling, oor die vraagstuk van die "cooperatio" van Maria in die verlossingsplan. Dit staan vas dat aan Maria 'n sekere bemiddellingsplek toegeken word. Die Roomskatolieke geleerde, G. D. Smith, verklaar: "The 'co-operation of the mother with the Redeemer who was her Son, differs not only in degree, but also in kind, from that of any other saint. For the consent alone He waited when He sent Gabriël to her presence ... He alone redeemed us, yet He deigned to associate His mother with His work of redemption. Mary is the cause of our salvation, even as Eve was the cause of our ruin . . . we can all co-operate with our most holy Redeemer, yet Mary's co-operation stands alone; similarly we can all pray one for another through Christ our Lord, yet Mary's mediation and the efficacy of Mary's prayer is something by itself, unlike that of any other creature". In hierdie diskussie is sprake van 'n ,dienede medewerking" (cooperatio ministerialis) terwyl andere praat van 'n medewerking asmede-verlosseres (coredemptrix) $^{60}$ ). M. J. Scheeben waarsku dat die woord „Coredemptrix met restriksie gebruik moet word om misverstande te voorkom, en stel voor dat die term ,adiutrix” (helpster) gebruik

58) B. Bartmann: A.W. I, bls. 464 .

59) G. D. Smith: The Teaching of the Catholic Church, Art. .,Mary, Mother of God" deur O. R. Vassall-Philips bls. $529 \mathrm{vv}$.

60) Dr. G. C. Berkouwer: "Conflict met Rome", 2de druk. Kampen 1949 (J. H. Kok) bls. 211. 
moet word $^{61}$ ) Heel sterk is die uitdrukking van FRIETHOFF wanneer hy i.v.m. Maria praat van „'n soort aanverwandskap met die Vader en die Heilige Gees". ${ }^{62}$ )

\section{(a) MARIA AS MEDE-VERLOSSERES. (Coredemptrix).}

Met grote nadruk wil die Roomskatolieke Kerk verklaar dat Christus die Verlosser is. Hierdie belydenis word breed en diep daargestel: Jesus Christus, Seun van God, ware God en ware mens is die Verlosser. ${ }^{63}$ ) Maria is nie die Verlosseres nie; sy is slegs mede-verlosseres . . , ,om zoo door zijn lijden en dood de verlossing voor ons te verdienen, en zij daarin met Hem mede moest werken"..$^{64}$ ) Die titel „Mede-verlosseres" het 'n breë en 'n engere betekenis: „Als medeverlosseres van de Heilige Drievuldigheid, inzonderheid van den Heiligen Geest, voerde Maria hct goddelijke Verlossingsplan mede uit; als medeverlosseres van haar Zoon nam zij deel aan Zijn leven, lijden en sterven. De eerste medeverlossing is gebruiklijk, de tweede moederlijk; als bruid van God stemde Maria, dienstbaar met alles in; als moeder van God bracht zij den Verlosser voort en door Hem, virtueel, de verlosten. De eerste opvatting breidt haar werk over geheel haar leven uit; de tweede verheerlijkt de moederlijke vruchtbaarheid en trouw". ${ }^{65}$ ) Haar werk as mede-verlosseres verloop in drie periodes:

Die periode van voorbereiding tot aan die menswording van Christus; die tyd van gesamentlike werksaamheid met Christus tot aan Sy dood; die tyd van haar meer selfstandige arbeid tot haar eie dood. ${ }^{66}$ ).

Meer versigtig as JANSSENS wil BARTMANN haar as medeverlosseres sien: „Nicht aber ist Maria Mittlerin im objectiven Sinne, als wenn sie an dem Erlösungswerke Christi einen aktiven, ursächlichen Anteil genommen und dieses Werk vervollstăndigt hătte, so dass wir, zwei Personen als Erlöser zu verehren hätten, einen „Erlöser" und eine „Miterlöserin (coredemptrix)”. Die meer besadigde BARTMANN sien hierdie titel as ,ganz neu, undurchführbar und wenigstens dogmatisch nicht zu verifizieren". ${ }^{6 \tau}$ Ook SCHEEBEN verklaar in dieselfde gees as BARTMANN: „Indesz

61) M. J. Scheeben: Dogmatik III, bls. 594, gesiteer deur Berkouwer: ,Conflict met Rome”, bls. 212.

62) C. Friethoff: „Katholieke Maria-leer” in die serie ..Waarheid en Leven", 1937, bis. 52 gesiteer deur Berkouwer, „Conflict met Rome”, bls. 212 .

63) George D. Smith: Mary's Part in our Redemption. Burns en Oates, London. Rev. Ed. 1954. bls. 27-46. Dr. Bartmann: Lehrbuch der Dogmatik. I bls. 328-353.

64) Prof. Dr. Malmberg: Wat Gelooven Zij? bls. 38-39.

65) E. M. Janssen S.J. in de Katholieke Kerk. I, bls. 575.

66) E. M. Janssen S.J. in De Katholieke Kerk, I, bls. 575-576.

6i) B. Bartmann: A.W. I, bls. 458 . 
haben wir trotz allen Suchens diesen Ausdruck vor dem 16 Jahrhundert nirgendwo gefunden, ,. ${ }^{88}$ )

Naas die stemme van BARTMANN en SCHEEBEN wat hier tot versigtigheid maan, verneem ons egter ander stemme soos die van JANSSENS wat verklaar: „Langs beide zijde strekt Maria's leven op aarde zich verder uit dan dat van Jezus: men mag het niet bssnoeien, als zou alleen wat met Jezus' voorbijgaan gelijtijdig verliep, belang hebben en waarde". ${ }^{69}$ ) Die "Little Flower Prayer Book" bevat die volgende woorde in 'n gebed: „I worship thee, great Queen and give thee thanks for the many favors ,thou hast bestowed on me in the past; most of all do I thank thee for having saved me from hell, which I so often deserved ... in thee I put all my trust, all my hope of salvation . . . Leave me not until you see me safe in heaven, there for endless ages to bless thee and sing thy praises. Amen". ${ }^{70}$ ) Ons vgl. ook die pouslike gebed vir die Mariajaar ${ }^{71}$ ).

\section{POUSLIKE GEBED VIR DIE MARIAJAAR.}

„O Maria, onbevlekte moeder van God en ook ons moeder, ons is verruk deur die luister van $u$ hemelse lieflikheid. Opgejaag deur die onrus van ons tyd werp ons onsself in $u$ arms. Ons is vol vertroue dat ons in $u$ liefhebbende hart die vervulling sal vind van ons vurige verlangens en 'n veilige toevlug teen die storms wat van alle kante op ons afkom.

Ons foute ontmoedig ons. 'n Grenslose lyding druk ons neer. Tog staan en bewonder en prys ons hoog die glorie sonder weerga van u hemelse gawes, waarmee God u meer as enig ander skepsel oorlaai het vanaf die eerste oomblik van $U$ ontvangenis tot die dag waarop $U$ tenhemelopgeneem is en gekroon is as koningin van die hemele.

O helder fontein van geloof, les die dors van ons siele met die ewige waarheid. $O$ geurige lelie van alle heiligheid, laat daardie hemelse geur ons harte betower. $U$ het die dood en die sonde oorwin, vervul ons daarom met 'n diepe afsku van die kwaad wat die siel 'n vyand van God en 'n slaaf van die hel maak.

$O$ uitverkorene van God, luister na die vurige roepstem wat uit elke hart opklink in hierdie jaar wat aan u toegewys is. Genees ons pynlike wonde. Bekeer die sondaars en droog die trane van die beproefdes en onderdruktes. Troos die armes en veronreg. tes. Blus die haat, versag die ruheid van sedes en waak oor die reinheid van die jeug.

68) M. J. Scheeben: Dogmatik III. bls. 594-595.

69) E. M. Janssens: „De Moeder Gods” in De Katholieke Kerk, I, bls. 575.

70) Gesiteer deur Berkouwer: Conflict met Rome. bls. 236.

71) Die Brug. Maandblad van die Katolieke Afrikanersentrum. Jaargang 3 no.: 1. Februarie 1954, bis. 1. Govert D. Vetten en Kie. (Edms.) Bpk. Kroonstd, O.V.S. 
Beskerm die heilige Kerk. Laat alle mense onder die bekoring kom van die Christelike deugde. Mag die mense by die hoor van $U$ naam, wat eensgesind in die hemel weerklink, mekaar as broeders beskou; mag die volkere hulself as lede van een gesin voel en só hulle koester in die son van 'n ware en algemene vrede.

$O$ liefste moeder, aanvaar ons nederige bede en bowe-al, verkry vir ons die genade dat ons eendag saam gelukkig met $U$, voor $\mathrm{U}$ troon daardie loflied mag herhaal wat vandag oor die ganse wêreld om $u$ altare weerklink: $U$ is die allerskoonste, o Maria! $\mathrm{U}$ is die roem, die vreugde, $\mathrm{U}$ is die trots van ons volk!"

"(As mens hierdie gebed met godsvrug en ootmoedigheid bid, kan elke Saterdag 'n aflaat van vyf jaar verdien word)".

Dit sou egter verkeerd wees indien ons die Roomskatolieke Kerk gaan be-oordeel slegs vanuit b.v. Janssens se ekstremisme. Die beste voorbeeld daarvan dat Mariologie en Christologie nie los van mekaar behoort te staan nie, het ons gevind by G .D. Smith $\left.{ }^{72}\right)$.

Smith stel dit duidelik dat die hele leer van die Verlossing verstaan moet word uit die feit dat die mensheid met God versoen is in Jesus Christus. Soos die mensheid in Adam geval het, so is hulle weer opgerig in Een, Jesus Christus. Voordat gepraat word van mede-verlossing moet hierdie feit van die verlossing in die Hoof van die liggaam duidelik verstaan word. Met die dood van Christus is die Verlossing voltooi. Opdat Sy verlossingswerk effektief kan word in diegenes vir wie Hy dit verrig het, moet die menslike geslag in Christus opgeneem word om die vrugte van Sy daad toe te eien. "It is in Christ that men are reconciled to God, in Christ that they become worthy of grace and salvation. ${ }^{33}$ ) Die leidende prinsipe is dat die lede van die liggaam gelykvormig (,conformable”) moet word aan die Hoof. Hierdie eerste heiliging van die lede van die mistieke liggaam, is nie die vrug van inisiatief van ons kant nie, maar is die resultaat van die uitgieting van die genade wat verdien is deur Jesus Christus, wat opgedra word aan ons deur die sewe sakramente, wat Smith vergelyk met 'n rivier van sewe strome, wat vloei uit die sy van die gekruisigde Heer. $^{(4}$ ) Die lede van die mistieke liggaam kan d.m.v. hierdie genade wat hulle ontvang het, self toeneem en groei in genade om vir hulle self 'n voorraad van goeie werke op te bou, wat God eenmaal in aanmerking sal neem, aan die einde van alle dinge; ja hierdie goeie werke gedy ook tot die welwese van andere, behalwe die daders self. ${ }^{75}$ ) In $\mathrm{lg}$. verband is alle lede

72) George D. Smith, D.D. Ph.D., Mary's Part in our Redemption. Burns and Oates, London. Rev. Ed. 1954.

i3) G. D. Smith: Mary's Part in our Redemption, bls. 27.

it) G. D. Smith: Mary's Part in our Redemption, bIs. 30.

i5) G. D. Smith: Mary's Part in our Redemption, bls. 32. 
van die liggaam mede-verlossers (co-redeemers) saam met die Hoof, almal is aktiewe oorsake (active causes) in die verwerwing van genade, onder Hom. Om nou die deelname van Maria in die Verlossingsplan van God te verstaan, begin Smith vanuit die analogie Adam-Christus die lyn deur te trek na Eva-Maria, soos reeds Irenaeus gedoen het. Deur 'n vrou het die dood gekom en deur 'n vrou die lewe, 'n vrou wat ,saam met Christus" sou werk om die lewe terug te gee. ${ }^{76}$ ) Die eer van die manlike geslag lê in die menslike natuur van Christus; die eer van die vrouegeslag in Sy moeder. Christus is die tweede Adam en Maria die tweede Eva, maar dan so verstaan: „... . it is only through the ,capital' merits of Christ, the mystical head of humanity, that Mary's merits can give us life".iT) As sy dan onbevlek ontvang is, dan was dit op grond van die verdienste van haar Seun. Indien sy dan vervul is met soveel liefde en genade wat sy kan uitdeel, dan is dit omdat Christus alles vir Sy moeder verdien het. „Of Mary, as of us, it is true that her merits are God's gift. Of herself she has nothing. ${ }^{78}$ ) Wat die Verlossingswerk van Christus betref, is die H. Skrif duidelik, vgl. Rom. 5 en 1 Kor. 15 ens. Wat die verlossingswerk van Maria betref, het ons die onfeilbare uitspraak van die pous, dat Gen. 3 v. 15 betrekking het op Maria wat aan die sy van Christus, die stryd teen die Satan sal aanknoop.

Smith wil, wanneer hy praat oor Maria as mede-Verlosseres, vooropstel dat sy self verlos is en as mens verlos moes word, op grond van die toekomstige verdienste van Jesus Christus, haar Seun. Daar is egter die verskil: Met die oog op haar voorreg om moeder van die Seun van God te word, is sy begiftig met heiligende genade vanaf die eerste oomblik van haar menslike eksistensie. „Mary must be saved by Christ; but he saves her, not by raising her up, but by preventing her fall"."is)

Dat sy mede-Verlosseres genoem word, moet verder ook gesien word teen die agtergrond van haar "fundamentele waardigheid" as moeder van God. Sy en God die Vader sou dieselfde Seun hê... iets wat ons verstand kwalik kan bemeester. God is Sy Vader kragtens sy "vere Deus" en Maria is Sy moeder kragtens die „vere homo". God kon niemand meer liefgehad het as Sy moeder nie en daarom is dit logies om te aanvaar dat daar ook niemand met soveel genade as sy, toebedeel is nie. Nooit het sy teen God gesondig met gedagtes woorde of werke nie . . . "that the Mother of God could never offend God is the traditional

iii) Smith: Mary's Part, bls. 39.

ii) Smith: Mary's Part, bls. 41.

is) Smith: Mary's Part, bls. 41 .

79) Smith: Mary's Part, bls. 48. 
sentiment of Catholic faith . . it is the impossibility of sinning: impeccability". ${ }^{80}$ ) Sy was inderdaad vol van genade, welke genade daagliks vermeerder het.

Maria is mede-Verlosseres in die sin dat sy ons die Verlosser "gegee" het. As moeder van God beklee sy 'n waardigheid bokant mense en engele. Met haar ,fiat" het sy toegestem om die moeder van die Verlosser te word; sy moes 'n wilsbesluit neem. Hierdie "fiat" is die sleutelwoord van Maria se hele bestaan. ${ }^{81}$ ) Van die oomblik van haar "fiat" tot aan die voet van die kruis, was Maria intiem betrek in Sy Verlossingswerk, in haar hoedanigheid as moeder van die Verlosser. Deur Sy lyding, lewe en dood het sy saam-gely om die offer te volbring, dus saam-volbring vir die sonde van mensekinders, dus Co-redemptrix. ${ }^{82}$ )

Smith kwoteer die uitsprake van verskeie pouse wat haar die titel toegeken het, t.w. Leo XIII, Pius X, Benedictus XV, Pius XI en Pius XII, ${ }^{\mathbf{8}}$ ) maar voeg hy hieraan toe, dat dit goed verstaan moet word dat hierdie uitsprake nie ex cathedra gedoen is nie, maar wel in pouslike ensiklieke, apostoliese briewe ens. Hierdie uitsprake is dus nie onfeilbaar nie, maar staan nietemin in die hoogste agting as synde 'n opsomming van die algemene beskouings van bekwame teoloë. Hierdie uitsprake kan wel dien as 'n gids $^{\text {st) }}$ )

In watter sin is Maria dan Co-redemptrix? Weer sê Smith: Ons moenie vergeet dat daar een Middelaar is tussen God en die mense nie, die mens Christus Jesus. (1 Tim. 2 v. 5) dat daar geen ander naam onder die hemele aan die mens gegee is waardeur ons gered kan word nie. (Hand. 4 v. 12) „... the work of Redemption is attributed to the Word Incarnate in a sense in which it is incommunicable to others." ${ }^{85}$ ). Wanneer die woord "verlos" dan wel op ander toegepas word, kan dit nie in dieselfde sin bedoel wees as wanneer dit van Christus gebruik word nie. Die woord kan alleen na analogie (analogia) gebruik word, bv. God is goed. Mense is goed. Die goedheid van God is egter anders as die goedheid van die mense. Die genoegsaamheid van Sy verlossende aktiwiteit is sodanig dat ook die verlostes self daarin kan deel, in die sin van 1 Petr. 4v. 10:- „Namate elkeen 'n genadegawe ontvang het, moet julle daarmee mekaar dien ..." Solank ons in gedagte hou dat die term Co-redemptrix met voorbehoud op Maria van toepassing is en alleen na-analogie gebruik word, solank bestaan daar geen rede om beswaar daarteen te hê

80) Smith: Mary's Part, bls. 50, 51.

81) Smith: Mary's Part, bls. 69.

82) Smith: Mary's Part, bls. 80.

83) Smith: Mary's Part, bls. 80-85.

84) Smith: Mary's Part, bls. 85.

85) Smith: Mary's Part, bls. 87. 
nie. Diegenes wat haar hierdie titel toeken, het weldeeglik kennis geneem van Kol. 1 v. 19, 20. Dus:- „Mary's Co-redemption is in no way inconsistent with the unique, superabundant, universal and all-saving merit-atonement of Christ ${ }^{\mathrm{s} \hat{n}}$ ).

Smith oefen juis kritiek uit op die teoloë wat Maria as coredemptrix kwalifiseer op 'n wyse wat die middelaarskap van Christus kan verdring, of haar feitlik op gelyke voet met die Verlosser kan plaas. Hierdie teoloë moet nie vergeet dat Maria self verlos is nie. Maria se verdienste kan nie bydra tot die prys wat Christus moes betaal om die mensheid met God te versoen nie. Indien ons onderskeid sou maak tussen Maria se verlossing en die van ons, waarvoor een prys betaal is, die kosbare bloed van ons Verlosser, kan ons weet dat dit 'n onhoudbare standpunt is. ${ }^{8 i}$ ) Sy is lid van die mistieke liggaam; sy is nie die Hoof nie. Tog is haar medewerking met die Verlosser so dat geen ander lid van die mistieke liggaam haar kan ewenaar nie. „The meritatonement of the Head has a primordial, one might say a creative character which that of the members cannot possibly possess, precisely because they are members and not the head." ${ }^{8}$ ) Maria se verlosseres-aktiwiteit is van dieselfde soort as die van die gelowige, net buitengewoon uniek en nie te ewenaar nie. Ons moet egter onthou, sê Smith, dat Maria dan geen eie sonde sou gehad het waarvoor sy moes boet nie; daarom is haar lyding en smart aan God geoffer tesame met die lyding van die Seun vir die sonde van die menslike geslag; in hierdie $\sin$ is sy coredemptrix..$^{89}$ )

Die konsekwensies van haar mede-verlosseresskap is nie te onderskat nie. Dit beteken dat alle genade wat gegee is en gegee sal word tot aan die einde van die dae, aan die mens gegee is, eerstens en hoofsaaklik op grond van die verdienste van Christus, maar tweedens en sekondêr op grond van die verdienste van Maria. Inderdaad is dit ook 'n fundamentele stuk van die R.K. geloofsleer dat Maria die kanaal is waarlangs en waardeur alle genade vloei na die mens toe ${ }^{\text {pn}}$ ).

Samehangend met die vraag in hoeverre Maria coredemptrix is, kom ook die kwessie van haar middelaarskap ter sprake.

(b) MARIA AS (Mediatrix) MIDDELARES: Ook hier vind ons in die Roomskatolieke Teologie groot verdeeldheid van mening. Alleen die Heilige Vader, die Pous, sal ex cathedra, wanneer die tyd ryp is, die eenheid kan bewerkstellig.

86) Smith: Mary's Part, bls. 89-90.

87) Smith: Mary's Part, bls. 96-97.

88) Smith: Mary's Part, bls. 102.

89) Smith: Mary's Part, bls. 110.

90) Smith: Mary's Part, bls. 159-179. 
BARTMANN verklaar: „Maria ist durch die Geburt des Weltheilandes indirekt zum Heile der Welt in Beziehung getreten. Sie vermittelt uns das Heil, weil sie uns den Heiland gebär. In diesem Sinne nennt sie schon Irenaeus causa (nostrae) salutis, (A.H. 3, 22, 4). Weiter ist sie Mittlerin unseres Heiles im sekundären, abgeleiteten Sinne, in welchen es alle Heiligen sind". ${ }^{91}$ ) Veel verder as BARTMANN gaan JANSSENS wanneer hy na aanleiding van Hand. 1 v. 14 gaan skryf oor die middelaarskap van Maria. Maria is middelares op dubbele wyse, $\mathrm{nl}$. tussen Christus en die mens en tussen die mense en God. Sy is die ,heil van die verlorenes, oorsaak van die lewe, bron van die ewige lewe, moeder van die lewendes, deur van saligheid, moeder van die saligheid, oorsaak van die saligheid, herstelster van die menslike geslag . ..."92). JANSSENS voer as gronde vir sy bewerings aan: „Benamingen, gebeden, feesten, bedevaarten en oefeningen van godsvrucht, de Meimaand en de rozenkrans, het scapulier en de bijzondere toewijding, de congregaties en religieuze gemeenschappen: alle uitingen van de onafzienbare en aller verscheidenste Maria-devotie lijken bezield en gedreven door het geloof aan haar middelaarschap ... Want hoe sterk vestigde Leo XIII, in een van zijn Rozenkransencyclicken, daarop de aandacht, en hoe hielden Pius X, Benedictus XV en Pius XI, ieder opvolger naar het voorbeeld van zijn voorganger, de aandacht levendig ....",93).

Nicholas O'RAFFERTY eindig sy opstel oor die „Virgin Mother of Jesus Christ" met 'n gebed van Bernard van Clairveaux: "... If you are troubled by the enormity of your offences, if you are confused by the guilt of your consciense, if you are discouraged by the fear of judgement, if you are beginning to be swallowed up by abyss of sadness, if you are already falling into the precipice of despair, think of Mary ... With her assistance, you will arrive safely at the haven, and thus experience the power of the name of Mary". ${ }^{94}$ )

Nieteenstaande die meer nugtere beskouing van BARTMANN en SCHEEBEN kan JANSSENS nog praat van „Maria onze Middelares naast Christus onzen Middelaar” en verder: „wat Christus evenwaardig (de condigno) voor ons verdiende, verdiende Maria billikheidshalve (de congruo) . . . alle genaden vloeien ons toe door Maria's bemiddeling ... ${ }^{95}$ )

91) B. Bartmann: A.W. I, bls. 458.

?2) E. M. Janssens: „De Moeder Gods” in De Kath. Kerk, bls. 583 en 592.

93) E. M. Janssens: „De Moeder Gods" in De Kath. Kerk, I, bls. 593.

94) Rev. N. O'Rafferty: Instructions on Christian Doctrine. The apostles Creed bls. 140-141. Uitg. The Bruce Publishing Co., New York. 3de druk, 1948.

95) E. M. Janssens: „De Moeder Gods” in „De Kath. Kerk”, I, bls. 584. 
Alhoewel die Roomsk. teoloë oor hierdie saak verdeeld is, moet mens met die oog op die verlede, (dat hulle oor die immaculata conceptio ook verdeeld was) en die ewolusie van die dogma in die toekoms, die uitlating van VAN DER TEMPEL onderskryf: „Of spoedig die dag sal aanbreek waarop die middelaarskap van Maria as leerstuk van ons heilige geloof sal verklaar word, is nog in die duister". ${ }^{9 c}$ )

\section{(c) DIE VIRGINITEITSIDEAAL:}

Die verdere sin en betekenis van hierdie dogma is saamgevat in die sin van die maagdelikheid, die selibaat, die hoogskatting van die virginiteitsideaal. Ons het reeds daarop gewys dat HARNACK die wortel van die virginiteitsstrewe in hierdie leerstuk vind. Ook BRUNNER wys daarop: „Sie hat darum auch immer wieder der Förderung asketisch-geschlechtsfeindlicher Strömungen gedient, ganz abgesehen davon, dass sie eine Hauptstütze der Marienverehrung geworden ist" $\ldots .^{97}$ ).

Daar bestaan tans in sekere Roomskatolieke kringe 'n groot mate van verontrusting oor die feit dat die waarde van die sakarament van die huwelik die laaste jare in besonderhede uitgewerk en beklemtoon word, terwyl die staat van die maagdelikheid, wat ,beter en meer verhewe is”, minder aandag geniet. Hierdie feit word dan nog in die hand gewerk deur die optimisties-humanistiese stroming van die tyd waardeur die maagdelikheid gesien word as 'n verouderde negatiewe askese, „wat verdienstelik is slegs omdat dit moe!lik is". ${ }^{9}$ ) Die hedendaagse Roomskatolieke Teologie moet daarom as deel van sy taak aan. vaar om die superioriteit van die selibaat of "castitas perfecta" meerbegryplik te maak, om sodoende ook 'n diens te bewys aan talle jong mense wat as gevolg van die ongunstige tydsomstandighede nie tot 'n huwelik kan kom nie.

Die konsilie van Trente het verklaar: Si quis dixerit statum conjugalem anteponendum esse statui virginitas vel celibatus, et non esse melius ac beatius manere in virginitate aut celibatu quam jungi matrimonio: anathema sit. (Sess. 24. Can. 10, Denz. 981).

HOEGEN verklaar: „Als theologen gaan wij uit van het geloofspunt, dat de christelijke maagdelikheid in zich beter is dan het huwelijk"..$^{99}$ ) „Om met 'n eersame doel af te sien van die

*) J. J. v.d. Tempel: Art. „Maria Middelares en Medeverlosseres" in „Het Schild", 13de Jaargang 1931, bls. 71, gesiteer deur Berkouwer, Conflict met Rome, bls. 210 .

9i) Emil Brunner: Dogmatik Band 2, bls. 419-420.

9) Dr. A. Hoegen: Over de zin der maagdelikheid", art. in die Jaarboek 1950, Voordrachten en Gedachtenwisselingen" van die „Werkgenootschap van Katholieke Theologen in Nederland", bls. 141.

89) Dr. A. Hoegen: A.W. bls. 143. 
huwelik is opsigself al soveel voor te sê: mens is nie gebonde aan die sinlikheid en die "meeslepende animale genot" wat die menslike gees verstrik in die verganklike dinge, en in sy hoogtepunt, die gedagtes aangaande God, selfs onmoontlik maak ... uit die tradisies van die vaders hou ons vas dat hulle as grootste belemmering vir die omgang met God beskou het die „copula carnalis". ${ }^{100}$ ) Die huwelik is vir Thomas iets goeds omdat dit meebring 'n ,conjunctio spiritualis animorum" en 'n amicitia; tog bind dit die gees habitueel aan die skepsele en verganklike dinge. 'n Lewe wat onmiddellik en uitsluitend gerig is op die goddelike dinge in sigself, is hoër. Omdat die christelike maagdelikheid sig hiertoe leen, is dit 'n beter lewensstaat, volgens Thomas. Die maagdelikheid is 'n hulpmiddel vir die ,actus contemplationis" op die weg na die ,status perfectionis". ${ }^{101}$ )

Hierdie lewensstaat is vir die Roomskatoliek 'n religieuse offer van sy liefde tot Christus. „De vrijwillig om God gekosen eenzaamheid drijft weer naar inniger gemeenzaamheid met God. In feite is ten gevolge van de erfsonde het getrouwd zijn doorgaans een beletsel. Maar daarom kiest men dit uit als offer . . een ascetisch offer". ${ }^{102}$ )

Volgens die tydgees word die sin van die maagdelikheid hoofsaaklik gesien as 'n spaar van energie om te staan in die sigbare sosiale dienste, naastedienste. HOFGEN wys daarop dat hierdie beskouing vir die Roomskatoliek slegs sekondêr is. Primêr is dit om alles te verlaat en af te sien van die huwelik as hoogste aardse goed. So word mens ryp vir die geestelike verlowing en huwelik! Soos mens in die huwelik die geheim van jou liggaam uit liefde aan 'n ander toevertrou, so gee mens jou maagdelikheid uit liefde aan Jesus. Soos die seksuele lewe die aardse liefde voed, so is in die verseëling van hierdie vermoë 'n uiting en versterking van die bruidsliefde tot Christus. „Verhevener dan het huwelijk, is de Godgewijde maagdelijkheid omdat de maagdelijke mens Christus het grote offer brengt van het edelste al wat de aarde aan schoonheid biedt; doch vooral omdat de maagdelijkheid als stand de rechtstreeks verloving met Christus voltrekt, is zy hoog boven het huwelijk verheven". ${ }^{103}$ )

Hierdie ,sekondêre" waarde van die maagdelikheid wil HOEGEN so verstaan:-104)

Hy gaan uit van die vooronderstelling dat namate mens ,,meer geestelike werk verrig en 'n meer universele funksie in die menslike gemeenskap inneem", jou status as mens verhoog word. Die

100) Dr. A. Hoegen: A.W. bls. 145.

101) Dr. A. Hoegen: $A_{\perp} W$. bls. 146-148.

102 Dr. A. Hoegen: A.W. bls. 149.

$103)$ Dr. A. Hoegen: A.W. bls. 152.

104) Dr. A. W. Hoegen: ,Het Heilige Huwelijk” in ,.De Katholieke Kerk”, I, H. 6. bls. 1030-1037. 
ongehude staat bied in hierdie opsig uiteraard meer moontlikhede aan as die gehude staat. „De maagd kan zich meer geven aan het algemeen welzijn". Die staat van die maagdelikheid kweek as lewensstaat 'n geestelike vrugbaarheid en plant die gees van Christus voort ,deur die bediening van die genade-middele, die prediking van die Evangelie, die leiding van die siele en die beoefening van die christelike liefde ... Dink ons o.a. aan die priesters, kloosterlinge en soveel wat ongehuud bly, om beter hulle hele persoon te kan wy aan verpleging, onderwys, jeugleiding, maatskaplike werk en gesinshulp. Die waarde van die maagdelikheid is dus geleë in iets positiefs, nl. in die funksie of taak wat iemand in diens "van die hoogste goed" vervul en nie allereers in die negatiewe ontsegging van die seksuele lewe nie.

Die grond van hierdie spesifiek Roomskatolieke etiese visie is terug te voer tot die perpetuele virginiteit van Maria: , . . . elke maagdelijke bemiddeling is een telkens persoonlijke, een deelnemende navolging van Marias leven, lijden en sterven . . . voor de maagden is Maria de ideële maagd-en-middelares . . . Maria's verdienste stichtte onder de mensen, de maagdelijkheid en de liefde ... geen prieser anderzijds, zelfs Christus niet, oefende zijn ambt ooit uit, zonder dat eerst een maagd de liefde uit de aarde had doen priemen. Als priester en als maagd, beiden de allereersten en de oertypen, staan, in hun bemiddeling, Jezus en Maria tegenover elkander, vullen zij elkander aan". ${ }^{105}$ )

Soas wat Maria die maagd onder die maagde is, die ideale maagd, so is sy in die R.K. Etiek ook die bruid onder die bruide en die moeder onder die moeders. ${ }^{108}$ ) As die ideale moeder is sy die oerbeeld en die oorsprong van elke ware moeder. „Die moederskap van Maria, waarin goddelike bruidskap en maagdelikheid sigself oortref, neem alle vroulike volmaaktheid geheel in sig op. Maria is die vrou; met net soveel reg kan ons verklaar: Maria is die moeder . . . die hoogste vroulike volmaaktheid . . . elke moederlike vrugbaarheid is deelname aan hare ... elke vroulike volmaaktheid gaan van haar volmaaktheid uit". ${ }^{107}$ ).

Op allerlei lewensterreine is die invloed van die geloof aan die R.K. Mariologie sigbaar. Maria en die Kerk is albei bruid van God en daarom moet die glans van die heerlikheid van Maria ook in die Kerk gesien word.

105) E. M. Janssen: „.De Moeder Gods” in „De Katholieke Kerk” I, bls. 584.587.

106) E. M. Janssen: „De Moeder Gods” in „De Katholieke Kerk” I, bls. $530-532$.

107) E. M. Janssen: „De Moeder Gods” in „De Katholieke Kerk” I, bls. 521.

Vgl. ook G. D. Smith: Mary's Part . . . bls. 117-127. 
Sagte nederigheid, teerheid en minlikheid, vriendelikheid en meegevoel - ja alle christelike deugde gaan terug tot haar; „ook by de meest gespannen heldhaftigheid houdt zij het evenwicht, teer en begrijpen . . Hoe de Maria-verering de vrouw eerbiedigen doet en de vrouwlijke deugden ontwikkelt. Hoe zij de kultuur met charitas doordesemt; zo dat deze op een ongeëvenaarde wijze de mensen verfijnt, verdiept en veredelt . . . Over Maria en de kunst, die de tover is van haar aanwezigheid! . . Over Maria en de vrouw! Hoe zij, in elke goede vrouw, zich vluchtig vertoont, en hoe elke goede vrouw opwijst naar haar voortreffelijkheid ...

. . . Nu moeten Maria en de Marialeer ons leven beïnvloeden; meer en beter moeten we de Moeder Gods vereren, edeler ons open stellen voor haar genade. Gods moeder en de onze, wij weten het nu, beheerst en bezielt alles: verrassende vergezichten legde dit of dat bijzondere onderzoek ons open, en hoe sterk deed ons de liefde, door Maria zelf meegedeeld, opgaan naar heiligheid en goed-doen!" ${ }^{108}$ )

\section{(d) MARIA AS HEMELKONINGIN:}

In die begin van hierdie eeu kon BARTMANN aangaande die „hemelvaart" van Haria nog verklaar dat dit slegs 'n „vrome mening" is. "Sie ist eine in der Kirche angenommene fromme Meinung, welche seit dem 6 Jahrhundert auch in einer eigenen Festfeier „Marais Himmelfahrt” (15 August) ihren äusseren Ausdruck erhielt und später, im Mittelalter, in der populären Unterweisung wie auch in den theologischen Schriften Eröterung und Verteidigung fand". ${ }^{109}$ )

Hierdie „vrome mening” het kragtens die ewolusie van die dogma gegroei tot dit in 1950 as formele dogma ex cathedra afgekondig is en dit nieteenstaande BARTMANN verklaar:,Die ersten Nachrichten hierüber entstammen nicht der Schrift. Auch die apostolische Tradition sagt davon nichts". ${ }^{110}$ ) Wel is dit duidelik dat die apokriewe boeke reeds die vierde eeu hierom. trent berig - maar voeg BARTMANN hieraan toe: „Als dogmatische Unterlage können solche trüben Quellen durchaus nicht dienen. Die ganze Frage muss von dem historischen Boden auf den der theologischen Spekulation verlegt werden". ${ }^{111}$ )

108) E. M. Janssens: De Katholieke Kerk, I, bls. 608-609.

109) B. Bartmann: Lehrbuch I, bls. 460.

110) B. Bartmann: Lehrbuch I, bls. 460 .

111) B. Bartmann: Lehrbuch I, bls. 460 . 
Hierdie "theologische Spekulation" is andermaal te sien onder drie gesigspunte: ${ }^{12}$ )

(a) Die kerklike tradisie en leer omtrent die verheerliking van Maria.

(b) Die kroning van Maria in die hemel.

(c) Die volheid van haar koninginskap.

Of die dogma van die liggaamlike hemelvaart van Maria die logiese afsluiting sal wees van die R.K. Mariologie is, o.i. te betwyfel. Die vrae na haar bemiddeling in die heil van die sondaars, haar middelaarskap en (mede)verlosseresskap sal in die toekoms voortgaan om die weg te berei vir nog dogmas. Die blom is steeds besig om oop te kelk!

\section{GEVOLGTREKKING: DIE MARIOLOGIE STEUN OP DIE CHRIS- TOLOGIE IN DIE RK.K. staan die Mariologie nie alleen nie.}

Dit blyk dat die R.K. Kerk wel 'n soteriologie nahou op art. III van die Apostolicum. Tot dusver het ons aangetoon dat hierdie Soteriologie weer en weer mariologies uitgebeeld word en telkens deur die groei van die dogma mariologies belig word. Daarmee wil ons die R.K. Kerk die onreg aandoen deur te verklaar dat die Verlossingsleer (veral in die wetenskaplike teologies) slegs mariologies is nie, terwyl die Reformatoriese soteriologie niks anders as christologiesgebonde is nie. Trouens in elke Roomskatolieke dogmatiese handboek vind die Christologie sy plek in die Verlossings-leer. (Vgl. o.a. G.D. Smith en Bartmann). Ons het reeds daarop gewys dat die Roomskatolieke kerk leer dat die Verlosser Christus die Here is. Die teenstelling wat in 'n kontroversgesprek te berde sal kom, is dus nie christologie van die reformatoriese kant en mariologie van die Roomskatolieke kant nie. Art. III van die Apostolicum het in die Roomskatolieke kerk baie beslis christologiese betekenis:- „Jesus Christus, geboren aus der Jungfrau, ist der. natürliche Sohn Gottes, die zweie Person in der Gottheit, Gott im wahren und eigentlichen Sinne ... Dieser Satz ist ein Fundamentalartikel ... Sie behauptet, dass der von Maria geborene Mensch, Jesus von Nazareth, zugleich der Sohn Gottes ist, und zwar im eigentlichen,

112) E. M. Janssen: „De Moeder Gods” in „De Kath. Kerk” I, bls. 596 tot 606 .

Vgl. ook G. D. Smith: Mary's Part in our Redemption, bls. 128-139. 
natürlichen Sinne, und somit die göttliche Natur oder Wesenheit besitz konsubstantial dem Vater, wie auch konsubstantial „mit uns". ${ }^{113}$ )

Die teenstelling tussen Rome en Reformasie t.o.v. die Soteriologie, is te omskryf as christologies-mariologies aan die een kant en enkel-christologies aan die anderkant. 'n Plus het tog langs Christus te staan gekom!

(Die reformatoriese sin en betekenis van artikel 3 (B) van die Apostolicum, die "antwoord" van die Reformasie op die Roomse mariologiese Soteriologie, is die onderwerp vir 'n ander artikel. Hier is slegs die Roomskatolieke standpunt(e) weergegee.)

113) B. Bartmann: A.W., bls. 333 . 